\title{
Direct and moderation effects on U.S. apparel manufacturers' engagement in network ties
}

\author{
Nancy J. Miller ${ }^{1}$ (D), Carol Engel-Enright ${ }^{2}$, \\ David A. Brown ${ }^{3}$
}

\begin{abstract}
PURPOSE: Firms do not continue and prosper purely on their own individual endeavors, as each firm is influenced by the activities of others, and thus direct and indirect relationships shape the firm's strategic management. These relationships form the tactics by which knowledge and other strategically important resources are accessed and created. Forming and maintaining ties among members of a network have been the subject of numerous research studies in the social, economic, and business literature. Our work is framed by the resource-based view of the firm perspective along with social capital theory and its shared constructs in network theory. Prior findings suggest that networking ties are strategic actions generated for firm growth and continuance. The ties may be short-term or develop into long-term relationships. The intent of this research is to fill some of the gaps in interorganizational networking strategy by analyzing five antecedents that have been suggested in the literature as individually associated with entrepreneurs' engagement in network ties. In this way, our work provides another research avenue for examining networking's contribution to strategic management. We hypothesized positive connections to entrepreneurs' engagement in network ties from antecedents involving the firm's knowledge absorptive capacity, business goals, entrepreneurial orientation, social interactions, and support from their environment. METHODOLOGY: In our quantitative approach, we tested our proposed macrolevel direct and moderating connections through an online survey of 125 U.S. apparel manufacturing firms. The apparel manufacturing sector in the U.S., as in many countries, has struggled with multiple disrupting factors contributing to the sector's decline in firm continuance. FINDINGS: The results from

1 Nancy J. Miller, Ph.D., Professor, Colorado State University, Department of Design and Merchandising, Fort Collins, email: nancy.miller@colostate.edu (ORCID ID: http://orcid.org/0000-0002-4610-7589).

2 Carol Engel-Enright Ph.D., Assistant Professor, Colorado State University, Department of Design and Merchandising, Fort Collins, email: carol.engel-enright@colostate.edu

3 David A. Brown, Ph.D. Candidate, Colorado State University, Department of Statistics, Fort Collins, email: david. alexander.brown@colostate.edu
\end{abstract}

Received 18 December 2020; Revised 10 February 2021, 23 February 2021; Accepted 31 March 2021. This is an open access article under the CC BY license (https://creativecommons.org/licenses/by/4.0/legalcode). 
OLS regression analyses support our hypothesized connections in that each of the five antecedents significantly contributed to entrepreneurs' engagement in network ties; however, when all five were collectively examined only absorptive capacity, social interaction, and business goals were significant $\left(R^{2}=0.58\right)$. Further examination of moderation effects found the entrepreneurs' perceptions of a supportive environment to modify both entrepreneurial orientation and business goals. RESEARCH AND PRACTICAL IMPLICATIONS: The effects of a supportive environment on business goals' relationship with network ties were greater when perceptions of a supportive environment decreased, while the effects of a supportive environment on entrepreneurship orientation's relationship with network ties were greater when perceptions of a supportive environment increased suggesting further study of U.S. entrepreneurs' perceptions of their environments. Entrepreneurs' interested in building domestic and international supply chain ties may find network ties provide one solution for adapting the firm's resources for global competitiveness. Future studies may direct attention to other industry sectors or countries for replication with larger sample sizes as we recognize the limitations to generalizability and scale refinement due to our limited sample size. ORIGINALITY AND VALUE: The examination of five constructs to shed light on how an organization's decisions may relate to engaging in networks and provides theoretical as well as practical implications that contribute to the larger organizational system framework.

Keywords : absorptive capacity, social interaction, business goals, entrepreneurial orientation, supporting environment, network ties

\section{INTRODUCTION}

A proliferation of research has focused on social capital and entrepreneurial networking (Burt, 1992; Galkina \& Atkova, 2020). However, market uncertainty continues to grow, as does interfirm network building as a strategy for advancement of entrepreneurial endeavors. For the entrepreneur, establishing a business strategy involves a balancing of opportunity, resources, and team (Aldrich \& Zimmer, 1986; Brush, Greene, Hart, \& Haller, 2001; Leyden, Link, \& Siegel, 2014; Timmons, 1999). Badaracco (1989) considered the word 'strategy' to describe "a company's basic long-term goals and objectives and the ways in which its managers take action and allocate resources to accomplish these goals" (p. 8). An example of a company strategy examined in this study involves engaging in network ties as an outcome of entrepreneurial decisions involving establishing business goals, building knowledge, developing social interactions, considering the business environment, and their entrepreneurial orientations. In the evolving field of entrepreneurship research, Carlsson et al. (2013) define entrepreneurship from the point of view of the Prize Committee who determines the annual International Award for Entrepreneurship and Small Business Research. They considered 
entrepreneurship as, "an economic function that is carried out by individuals, entrepreneurs, acting independently or within organizations, to perceive and create new opportunities and to introduce their ideas into the market, under uncertainty, by making decisions about location, product design, resource use, institutions, and reward systems. The entrepreneurial activity and the entrepreneurial ventures are influenced by the socioeconomic environment and result ultimately in economic growth and human welfare" (p. 914).

Opportunities for fortifying a competitive advantage and firm success, frequently require leveraging networks of internal and external ties that motivate new ways of exchanging and combining resources (Mazzarol, Rebout, \& Soutar, 2009; Tretiakov, Bensemann, Sanders, \& Golloway, 2019). There has been a long-standing flow of research that views networks as a form of social capital (Burt, 1992; Galkina \& Atkova, 2020). Early research on networks focused on social ties as conduits for information and resource sharing (Adler \& Kwon, 2002; Burt, 1992; Granovetter, 1985; Portes, 1998; Putnam, 1995; Tsai \& Ghoshal, 1998; Uzzi, 1996; Uzzi, 1997). Over the past three decades, a significant body of research has investigated similar dynamics at the organizational level (e.g., Ahuja, 2000; Barzak, 2017; Gulati, 1999; Gulati, Lavie, \& Madhavan, 2011; Hakansson \& Snehota, 1989), and specifically at the business level (e.g., Moliterno \& Mahony, 2014; Todeva, 2014; Zin \& Ibrahim, 2020).

Interorganizational networking, as a strategic approach, has been positioned in numerous studies as assisting in firm growth by securing access to resources (Lavie, 2006). To aid in securing resources, a firm is compelled to maintain multiple co-occurring ties that cultivate social capital (Barczak, 2017). Jarillo (1988) considered networks as a strategic means used by entrepreneurs to build a strong competitive stance in the marketplace. Though there is no universally accepted definition of a network organization, Jones, Hesterly, and Borgatti (1997) considered a business network organization to entail an intentionally selected, structured group of individual companies, involved in goods manufacturing and delivery of service, operating under an open-ended agreement that ensures flexibility in meeting the changing environment and utilizes coordinated and protected transactions of change. Management literature has suggested further consideration of advancing traditional strategic management to include the strategic formation of networks as well as the need to alter resource-based concepts to understand better the strategy of interorganizational ties (Krzakiewicz \& Cyfert, 2013). Thus, concepts from the resource-based view of the firm (RBV) and social capital theory have served as frameworks for prior strategic management research. The contribution of this study rests in including resource-based view of the firm concepts and concepts from social capital theory and network theory, 
to discover relationships that have not been examined together in providing a broader understanding of entrepreneurs' engagement in interfirm network ties. The aim of this present study is to address gaps in interfirm networking by: 1.) analyzing notable management actions or perceptions that have been previously found to be independently associated with entrepreneurial network ties; 2 .) examining these antecedents for their collective association with network ties; and 3.) exploring potential interactions or moderating effects of these firm-level antecedents for entrepreneurs' engagement in network ties. Our overall objective in this approach is to widen the focus in examining these antecedents as properties of the firm, which may act as determinants of organizational engagement in network ties, for integrating a broader understanding of strategic network management interactions and implications (Gulati et al., 2011).

We gain greater insights into firm owner networking strategy by examining entrepreneurs' knowledge absorptive capacity, business goals, entrepreneurial orientation (EO), social interactions, and perceptions of a supporting environment. This list of antecedents, examined for their impact on engaging in networking ties as the dependent variable, is by no means comprehensive, but essentially reflects some broadly defined areas where we see some of the greatest potential for applying a network strategy lens. In addition, many of the proposed variables have been described as interrelated; thus we examine concepts for strategic networking in a relational model. Our answer shifts attention away from the more traditional notions involving the study of networking by characteristics of the network and position of the firm in the network, evolution of the network, and effects of networking on business performance. This paper consequently focuses attention in more detail to examine potential interactions among the antecedents in exploring their connections with network tie engagement.

To address our study's aims, we focus on firms in the U.S. apparel manufacturing sector. In a manner not unlike what has affected U.S. manufacturing in general, few have felt the impact of intensive low-cost competition from globalization and increased technology more acutely than the apparel industries. The situation is not isolated to U.S. industries and has been reported in other nations in terms of manufacturing SMEs (Craig, McNamara, Descubes, \& Guerin; 2020; Fuller-Love \& Thomas, 2004). These disrupting factors have contributed to the large decline in the related industries' employment levels over many decades due to mills and apparel factories going out of business (Anderson, Berg, Hedrich, Ibanez, Janmark, \& Magnus, 2018; Gerber Technology, 2019). A significant factor contributing to the decline can be attributed to the number of firms that failed to adopt new technology, cooperate with other firms to reduce costs, and to develop product 
innovations that could have provided a competitive position in the global market (Mittelhauser, 1997). Craig et al. (2020) found that informal networks served to build international linkages with suppliers and distributors beyond small, French manufacturing firms. They also found that networking which allowed an exchange of information, thus advancing the firms' knowledge absorptive capacity, was an important factor in mitigating environmental uncertainties. Many apparel manufacturing companies face the formidable task of implementing solutions for staying viable, and are seeking resources and knowledge as to how and with whom they might invest in nearshoring, automation technology, and sustainability (Anderson et al., 2018). Given the challenges, the global apparel industry is still one of the most important industries, generating $\$ 450$ billion annually, and is one of the most important employers in developing countries (The Apparel Industry, 2017).

Our paper is organized as follows. The literature review elaborates on the introduction, provides a review of the variables and proposed relationships, and advances the formulation of six hypotheses. The next section comprises the research methods, testing of hypotheses, and the results. The final section presents a discussion with reference to the literature and offers conclusions along with limitations of the study and suggestions for further research.

\section{THEORETICAL BACKGROUND AND HYPOTHESIS DEVELOPMENT}

The framework for our study follows the work of Lavie (2006) as well as Gulati et al. (2011) and their reformulated version of the RBV that incorporates the impact of efforts and activities to secure network resources. They consider interorganizational networking, as a strategic approach, to assist in firm growth by securing access to resources. In these prior works, the researchers, along with several others, also considered social capital aspects inherent in social networking (Eisenhardt \& Schoonhoven, 1996; Greve \& Salaff, 2001; Rehman, 2015). Networking research contends that external resources, activities, and participants are likely to hold greater influences on the firm, than its own internal resources and activities (Ford \& Mouzas, 2013). We integrate and extend the RBV perspective to examine firm owners' strategies as well as aspects of social capital and networking theory to account for the impacts on engaging in network ties. This study does not attempt to investigate a complete or in-depth compellation of possible relationships of the firms in their actions to buy and sell within the market environment (Barczak, 2017). Further, no claim is made about the type of network or the boundaries, but rather that a firm's multiple forms of effort to enhance their business will coincide with increased engagement in network ties. Our 
approach corresponds with Ibarra's (1992) view that macrolevel studies have contributed greatly to network-analytical research.

\section{Resource-based view of the firm perspective}

The core of business strategy involves the organization's effectiveness in gathering resources, which is recognized as a function of the match between the characteristics of the environment and the organizations capabilities (Hakansson \& Snehota, 1989). The resource-based view (RBV) is a framework in management that has been applied in determining the strategic resources a firm attempts to gather to achieve and sustain competitive advantage (Barney, 1991). From the RBV perspective, the emphasis is on strategic choices that firms employ for securing key resources deployed in the market for maximizing returns. The original RBV perspective focused on the firm's internal resources and capabilities (Barney, 1991), but evolution of the perspective has included the firm's efforts for securing resources through external channels such as interorganizational networking (Barney, Wright, \& Ketchen, 2001; Ford \& Mouzas, 2013; Guliati et al., 2011; Gulati, Nohria, \& Zaheer, 2000). In this current work, we view the firm's attempts to gain tangible and intangible resources from multiple overlapping standpoints grounded in strategic management. We follow Sobolewska's (2020) view that externally gained knowledge is a complementary resource that is considered as an opportunity, accessed through networking, to supplement the firm's own insufficient resources. In entrepreneurship and strategic management, resource management is a dynamic capability necessary for survival and continuance, particularly under conditions of environmental uncertainty and recognized resource scarcity (Brush et al., 2001; Grichnik, Brinckmann, Singh, \& Manigart, 2014). We focus on knowledge absorptive capacity as a firm's ability to incorporate new knowledge (Lis \& Sudolska, 2017).

Prior related research involving the RBV perspective includes Krieser's (2011) work that considered entrepreneurship orientation (EO) as a resourceintensive strategic approach. He suggested firms use EO to unite new with existing knowledge-based resources through network relationships. This perspective assumes that firms recognize the value of networking as a resource for knowledge garnering and incorporate the concept of networking in their EO.

In this present study we examine the direct roles that both EO and knowledge absorptive capacity play in engaging in network ties, and the potential interaction between $\mathrm{EO}$ and absorptive capacity in their relationship with network tie engagement. 
Research has also focused on goal setting strategies in terms of acquiring resources for business development. Kelliher, Murphy, and Harrington (2020) found business planning activities and goal setting contributed to strategic learning, enabling the business to identify solutions that enhanced the strategic capability of the organization over time. Their in-depth casework examined relationships between goal-oriented activities and knowledgebased resource absorption. Business goals are considered the direction or motivation leading to the use of knowledge. Thus, we examine the direct roles that business goals and knowledge absorptive capacity hold in engaging in network ties, as well as the potential moderators of these relationships. Williams, Manley, Aaron, and Daniel (2018) found strong support for goals in achievement of firm performance, suggesting business goal setting as an important strategic approach. Their work did not detail the nature of the goals, nor whether the firms were focused on acquiring resources or engaged in network ties. Past work by Locke, Latham, and Erez (1988) emphasizes the long-standing belief that goal setting is supported by goal commitment. Their theoretical work proposed three factors that affect goal commitment involving external influences from authority figures and peers, interactive factors focusing on participation and competition, and internal factors concerning expectancy and internal rewards. Our work will investigate aspects inherent in these three factors, in that network tie engagement may provide the influence of peers, prospects for participation in meeting competitive aspects of the marketplace, as well as the occasion for social interaction opportunities, and evaluation of supportive environments.

From the RBV perspective, we synthesize prior empirical findings to reexamine strategies associated with resource accumulation perceptions of the firm's environment, social interactions, and business goals in tangent with EO and knowledge absorptive capacity. We aim to extend our findings by introducing encompassing variables that moderate the relationship with network tie engagement, specifically, knowledge absorptive capacity, entrepreneurial orientation, and business goals in tangent with social capital concepts involving social interactions and a supportive environment

\section{Social capital theory}

Bourdieu (1986) defined social capital, among the various forms of capital, as the sum of actual or potential resources linked to membership in a group, such as a network, providing maintained and reinforced exchanges that accrue material and symbolic profits for the members. Social capital, as defined by Putnam (1995), involves, "features of social life, such as networks, norms, and trust - that enable participants to act together more effectively 
to pursue shared objectives" (p. 665). There is also recognition that social capital may be formal or informal in nature as well as holding both individual and collective characteristics (Woolcock, 1998). Social capital is, at its core, about relationships and ties.

Social capital has been found to be both an input to, and an output from, social and economic processes (Gannon \& Roberts, 2020). Social capital includes the dimension of social interaction (Tsai \& Groshal, 1998). Entrepreneurs develop relationships, particularly interfirm arrangements, to obtain resources such as information or knowledge. The bonds stimulate opportunities for exchange or combining of resources with other firms (Hitt, Dacin, Levitas, Arregle, \& Borza, 2000). Organizations with a positive social interaction culture often interact frequently (Connelly \& Kelloway, 2003), knowledge is shared, and greater access to resources is provided (Toutain, Fayolle, Pittaway, \& Diamanto, 2017). Nahapiet and Groshal (1998) presented three dimensions of social capital - structural, relational, and cognitive. The relational dimension of social capital includes social interaction found to provide advantages for the individuals through information and specific resources (Tsai \& Groshal, 1998).

Assessment of the environmental, social, and economic supportive conditions is considered important in overcoming or adapting to uncertainties (Bitowska, 2020). There is a combination of factors involved in the socioeconomic environment that can inhibit or support business advancement. Paliokaite (2019) regarded environmental conditions as affecting the firm's knowledge absorptive capacity. There is agreement among scholars that the more conducive the environment is to aspects of conducting business, the more likely the business will develop and grow (Gynawali \& Fogel, 1994). Thorelli (1986) proposed that the most significant part of any firm's environment was other firms; thus interfirm linkages and perceptions of other firms were important to understanding entrepreneurial behavior. Our work examines the perceived presence of social and economic assistance and backing in the entrepreneurial environment, and the provision of a supporting environment to engage in network ties.

While the theoretical origin of social capital has been disputed, the majority of recent scholarship references Coleman's (1988) work (Engbers, Thompson, \& Slapper, 2017). Social capital has found a place in a wide array of disciplines. Over the years, a proliferation of research has focused on social capital and entrepreneurial networking (e.g., Burt, 1992; Galkina \& Atkova, 2020). Networks have been regarded as sustained relationships between individuals, groups, and organizations such as firms (Dubini \& Aldrich, 1991; Thorelli, 1986). Business networks have been defined as an assembly of exchange relationships between companies (Marcela Herrera Bernal, Burr \& 
Johnsen, 2002). Past research has yielded empirical evidence that social capital holds real effects on the likelihood that the entrepreneur will hold interfirm linkages. These connections enhance performance, innovations, and the prospect of firm continuance, thus contributing to job creation and economic growth (Greve \& Salaff, 2001; Ibarra, 1993; Nyuur, Brecic, \& Debrah, 2018).

A brief overview offers further understanding of the intricate advancement of social capital's conceptualization of networking, from its focus on the social aspects of interactions, to its adoption for studies of business interactions. Early work proposed by Hakansson and Snehota (1989), presented a network model of organization-environment interface that focused on the functioning of business markets and advanced networking as a business strategy. Borch and Arthur (1995) recommended strategic network frameworks to provide researchers with a broader perspective as to the complex interactions between the firm exchange and the social ties of those involved. They emphasized building a multi-disciplinary theoretical approach. This perspective follows Granovetter's (1992) thinking that the development of a firm resulted, "from socially situated individuals embedded in networks of personal relations with noneconomic as well as economic aims" (p. 47). Thus, business exchange could help the entrepreneur gain social support in maintaining self-confidence, as well as acquiring social networks aiding the acquisition of legitimacy in the marketplace (Johannisson, Alexanderson, Nowicki \& Senneseth, 1994).

Studies in organizational change recognized the importance of social networking concepts in meeting the volatile competitive landscape (Tenkasi $\&$ Chesmore, 2003). At this same time, social networks were considered the glue in the mobilization of resources for entrepreneurial innovations. This approach by Greve and Salaff (2001) was called corporate social capital. Work in strategic management considered that constructing a resource-based view was, for the entrepreneur, enormously challenging and considered that resources were the keystone for strategy (Brush et al., 2001). Consequently, both business and social benefits characterized why entrepreneurs sought networking opportunities. Ahuja (2000) examined interfirm linkages as opportunities, weighing up the contributions of the resource-based view of the firm (RBV), as well as social, technical, and commercial capitals. He called for empirical steps that included a broader set of factors proposed to influence network development and to recognize the motivations for networking.

\section{Network theory}

Management research has considered the effect of social networks on a broad range of organizational practices resulting in an integration to form organizational social network literature (Kim, Oh, \& Swaminathan, 2006). 
Larson and Starr (1993) proposed, and Miller, Besser, and Sattler Weber (2010) empirically considered, the network approach as an organization of multidimensional socioeconomic links. Moliterno and Mahony (2011) advanced the Network Theory of Organization, recognizing that organizational networks are hierarchically associated within a system of networks. Todeva (2014) considered business networks to be socio-economic configurations of transacting economic entities, involving people or organizations who participate in repeated exchanges. There is also recognition of embeddedness of these transactions in the formation of social relations.

Entrepreneurs are said to assemble networks that combine both social and business concerns with significant and lasting ties that are as often socially oriented as business oriented (Johannisson, 1996). Contemporary research is influenced by complexity theory to understand - effectual networks (Galkina \& Atkova, 2020), external and internal interactive learning (Thoma \& Zimmermann, 2020), both strategic niche management and social network analysis (Canie \& Romijnb, 2008; Gannon \& Roberts, 2020), industrial marketing and purchasing (Ford \& Mousas; 2013), and proximity and clusters (Camarena-Gil, Garrigues, \& Puig, 2020). Pellinen (2014) considered the bulk of entrepreneurship network studies to link network ties, as defined by Granovetter (1973), with firm performance. However, it is just as important to know what induces the entrepreneur to seek and build ties prior to measuring firm or network performance.

Networks are made up of a broad collection of cooperative ties ranging from information links to shared operations with arrangements that often blur company boundaries (Badaracco, 1989). These networks provide the firm with information, resources and advantages from learning that allow firms to achieve strategic goals (Johannisson, 1986; Miller, Besser \& Malshe, 2007; Yli-Renko, Autio, \& Sapienza, 2001) and enhance business performance (Besser \& Miller, 2010; Zin \& Ibrahim, 2020). The network is considered as an environment where a combination of resources is exchanged, impacting the individual in learning the entrepreneurial process (Toutain et al., 2017). Thus, the overlap of RBV, social capital, and network theory has been applied in prior studies involving a variety of firm types, sizes, and locations. The contribution of our study centers on examining constructs from many of these prior studies together in assessing their ability to explain entrepreneurs' engagement in network ties

\section{Network ties}

In discussing business network theory, Todeva (2014) indicated three distinct levels of focus - the level of the firms' attributes, the level of inter-firm 
relationships, and the level of overall network configuration. Our work is at the level of the firms' attributes concerning their efforts toward engaging in network ties. Network ties are considered the bonds that enable groups to act together, often with greater capabilities, in meeting meet uncertainties in the environment.

Tsai and Ghoshal (1998) refer to social ties as conduits for information and resource sharing. Within network strategy, an important focus is geared to the leveraging of a network of internal and external relational ties to assemble, escalate, or expand resources. Kreiser (2011) developed theoretical propositions regarding the role of entrepreneurial orientation and acquisition of knowledge-based resources through networking. Network ties have been examined for factors that may influence when strong versus weak ties generate benefits. Granovetter (1973) suggested that weak ties allow access to a diversity of resources through relationships outside the immediate contacts. Burt (1992) considered these connections as positions of bridging, allowing ties with otherwise unassociated outsiders. Hoang and Antoncic (2003) found support for bridging, in that strategically important information was exchanged sooner via weak ties than firms embedded in networks with strong ties. Uzzi $(1996,1997)$ understood that firms benefited from a combination of these ties. In the current work, our definition involves engaging in networking ties as a form of business strategy, rather than for the characteristics of the ties such as modalities of strong or weak, or the characteristics of the network structure.

Portes (1998) believed attaining social capital required purposeful investment, particularly in economic-based resources, and underscored the importance of separating the resources from the capacity to obtain them. Liu and Yang (2020) found that by developing ties across the interfirm network, the firm could access diverse resources providing it with competitive advantages. Areas suggested for future studies involving networking resources have included organizational culture (Felipe, Roldán, \& Leal-Rodríguez, 2017), absorptive capacity and knowledge acquisition (Limaj \& Bernroider, 2017; Norman, 2004; Parra-Requena, Ruiz-Ortega, GarciaVillaverde, \& Rodrigo-Alarcon, 2015). Thus, the focus on the capacity to obtain resources overlaps the resource-based view of the firm with concepts stemming from social capital, and particularly business network theory. The above theoretical perspectives suggest possible interactions between concepts. We highlight and form hypotheses to test the theoretically overlapping concepts of knowledge absorptive capacity, social interaction, business goals, entrepreneurial orientation, and supportive environment that are proposed as explaining a firm's engagement in network ties. 


\section{Hypotheses}

Measurement of aspects involved with social capital theory is considered extremely difficult (Engbers et al., 2017). Gannon and Roberts (2020) also emphasize the mismatch of social capital theory and empirical measurement in the economics literature. There is agreement that social capital is a multidimensional concept with potentially strong associations that, if uncovered, may verify complementary effects (Engbers et al., 2017). Borgotti and Halgin (2011) remind researchers to consider the node attributes or the other contextual factors as the proposed causal agents that, in our case, could interact in a study of firm engagement in networking ties. Investigated in this study are hypothesized relationships between the factors concerning knowledge absorptive capacity, social interaction, business goals, entrepreneurial orientation, and supportive environment, and entrepreneurs' interfirm network tie engagement.

\section{Knowledge absorptive capacity}

Knowledge and other strategically important resources are accessed and built, generating relations that are linked to other relations resulting in a system of what is referred to as business networks (McGowan, Cooper, Durkin, \& O'Kane, 2015). Knowledge transfer or migration, as a resource, is included in both the RBV perspective and in social capital theory. Knowledge absorptive capacity is referenced as a firm's ability to see opportunities and use information external to the firm to develop product and production methods (Greve \& Salaff, 2001; Lis \& Sudolska, 2017). Firms reach external information by way of ties suggesting that social capital is embedded in relationships that enhance absorptive capacity. Tenkasi and Chesmore (2003), in examining network ties for enhancing organizational change, referred to problems with knowledge transfer and learning, which are also elements involved in knowledge absorptive capacity. They found strong network ties were likely to promote greater communication and facilitate the exchange of information needed for knowledge transfer and learning. Organizational learning involves the linking of the firm's values and its corresponding behaviors (Garvin, 1993). Anderson, Covin, and Slevin (2009) specified that the two dimensions of strategic learning involved the acquisition of knowledge and the execution of strategic change due to the acquired knowledge. The premise of knowledge absorptive capacity is, according to Cohen and Levinthal (1990), that to be able to acquire and use new knowledge, the firm must have the capacity to recognize or understand how the new information corresponds with the existing firm-level knowledge. In other words, acquisition of knowledge 
may not be operationalized if it cannot be executed. In this way, knowledge becomes a crucial strategic resource.

The association of establishing strategic networks of interfirm ties to the accessing of resources and offering advantages has long been supported by the RBV perspective, social capital, and networking theory (Gulati et al., 2000; Lane \& Lubatkin; 1998). Thus, we hypothesize that knowledge absorptive capacity is an antecedent for engaging in network ties. Additionally, Paliokaite's (2019) work suggested absorptive capacity seeking facilitated connections for both intra-firm relationships and environmental conditions. In this current study we therefore also examine the moderating effects of absorptive capacity, social interactions, supporting environment, business goals, and EO on network ties. From social capital theory and the resourcebased view of the firm perspective we first conclude:

H1: As the firm owners' efforts to gain knowledge absorptive capacity increases, so will their engagement in network ties.

\section{Social interaction}

Aldrich and Zimmer (1986) highlighted the uncertain and faulty perceived nature of business environments and specified that a comprehensive description of entrepreneurship must include the social relationships by which resources, information and support are acquired. Work by Linder, Lechner, and Pelzel (2020) considered social interaction as a means of extracting benefits and suggested opportunity recognition was heightened with the process of entrepreneurial interactions. They proposed that the interactions were likely to lead to heterogeneity and constructively altered the exchange of resources.

Social capital, manifested as social interaction, is considered in the network literature to advance ties among the members (Tsai \& Groshal, 1998). The social ties are channels for information and resource exchange. The intensity of social interactions of entrepreneurs can be used as an indicator of social capital (Nahapiet \& Groshal, 1998). Social interactions overlook the boundaries between entrepreneurs providing opportunities for accessing knowledge resources (Molina-morales \& Martinez-fernandez, 2010; Tsai \& Ghoshal, 1998). Interactions can occur at social or business-focused events thus, the greater number of opportunities for social interactions with other firms, the greater the likelihood of exchange enhancing network ties. This perspective reflects opportunities from the resource-based view of the firm combined with social capital and network theory. In this present study, we examine the direct and moderating effects of social interactions on network 
tie relationships. From the development of social as well as business connections, we first hypothesize that:

H2: As the firm owners' social interaction increases, so will their engagement in network ties.

\section{Business goals}

From a long tradition in psychology, it has been established that deliberate behavior is purposeful or focused and is regulated by goals (Latham \& Locke, 1991). When describing the vital components of business planning, scholars note that strategic goals need definition as well as alternatives for achieving the goals (Armstrong, 1982; Brinckmann et al., 2010). Smeltzer, Van Hook, and Hutt (1991) found business owners who developed a business plan reported a higher quality and quantity of connections through their networks. Thus, through a combination of interactions and the advancing of common goals predicated upon cooperation among members of the network, the usefulness of the network is amended and furthered (Toutain et al., 2017). Defining goals requires the commitment of resources and thus the RBV perspective plays a role in decisions initiating competitive advantage.

Hakansson and Snehota (1989) noted a more complete understanding of the business organization resulted from a shift in business strategy focus away from the internal processes of firms and towards the interchange of the firm and its environment. Their definition of strategy held that, "the emphasis is on the pattern of activities which has an impact on the achievement of organizational goals in relation to its environment" (p.188). Brinkmann et al. (2010) viewed newer and smaller firms to be more affected by uncertainty in the environment due to limited information when compared to established larger firms. They also ascribed the moderating effect of cultural setting or the degree of uncertainty in the business planning-performance relationship.

Knowledge garnering opportunities and learning behaviors have also been identified as important to goal achievement as well as supporting environments that allow individuals to learn (van Gelderen, van de Sluis, \& Jansen, 2005). These prior research results suggest that either or both knowledge absorptive capacity and a supportive environment may hold a moderating effect on attainment of business goals when examining the relationships with network ties.

Within strategy, decisions are often the focused effort that guides the business and unites the team of employees. These decisions are generated from the owner's business goals that are embedded in the business planning (Mazzarol et al., 2009; Williams et al., 2018). This present study serves as 
a preliminary examination of how business plans guiding the development of network ties, may precede or direct business networking strategy. We also examine the direct as well as the moderating effects of business goals on network ties. We, therefore, first hypothesize:

H3: As the firm owners' efforts in meeting business goals increases, so will their engagement in network ties.

\section{Entrepreneurial orientation}

Entrepreneurial orientation (EO) was defined by Covin and Wales (2019) as "an attribute of organization that exists to the degree to which that organization supports and exhibits a sustained pattern of entrepreneurial behavior reflecting incidents of proactive new entry" (p. 5). Covin and Lumpkin (2011) considered the concept of EO to aid in an understanding of why and how some firms regenerated themselves for persistent growth while other firms did not. EO research has held many definitions with interest in identifying the number of dimensions involved.

Le Breton-Miller and Miller (2011) proposed a unidimensional approach to EO consisting of a set of dimensions involving innovativeness, risk taking and proactiveness. These dimensions were also examined previously by Covin and Slevin (1991) as well as Stam and Elfring (2008). We follow this logic and consider the formative construct of EO as the shared variance among the three dimensions recognizing that multiple components form the single variable. For the purposes of this study we follow the definitions also contained in EO research by Zbierowski (2020) and by Rezaei and Ortt (2018), whereas innovativeness involves the willingness to support originality and the incorporation of change to achieve a competitive advantage for the firm. Risk taking involves the extent to which the firm occasions business-related risks, and proactiveness entails responding to impending or forthcoming demand to amend or shape the environment.

Payne et al. (2011) suggested a multilevel research opportunity existed for examining the relationship between EO and social capital. Kreiser (2011) offered propositions involving the relationships among entrepreneurial orientation, learning, and networking. Stam and Elfring (2008) examined EO by studying the configuration of intra- and interindustry network ties and found the moderating effects of network ties influenced the relationship between EO and firm performance. They suggested further studies examining the determinants of external ties would make important contributions. Covin and Miller (2014) included examination of network ties in assessing the EO on 
a national and international level as a promising area in the field of strategy and organizational theory.

Long agreed upon across EO studies are the moderating effects of environmental conditions on the EO to performance relationships (Covin \& Lumpkin, 2011; Covin \& Wales, 2019). Higher levels of EO were found to influence positively an entrepreneur's strategic learning that was then disseminated through a social exchange process (Siren, Hakala, Wincent, \& Grichnik, 2017). These prior research results suggest that either or both knowledge absorptive capacity and a supportive environment may hold a moderating effect with EO when examining the relationships with network ties. In this present study, we examine the direct and moderating effects of EO on network tie relationships. We first hypothesize that:

H4: As the firm owners' entrepreneurial orientation increases, so will their engagement in network ties.

\section{Supportive environment}

In turbulent environments, firms cannot easily foresee which resources will be vitally important; thus it is crucial to invest in network relationships that are believed to increase the number and type of available resources (Johannisson, 1986; Sobolewska, 2020). Social and economic supportive environmental conditions were considered by Bitowska (2020) to be important in overcoming or adapting to uncertainties. Grichnik et al. (2014) examined the level of support from the environment as environmental munificence capturing entrepreneurs' responses to the perceived negative more hostile flipside of industry support. Dollinger (1990) defined munificence as the degree of resource abundance and capacity for supporting growth.

MacGregor (2004) submitted that firms with fewer than ten employees often sought networks as one solution for influence over the uncertain market environment. Firms with few resources are more vulnerable to risk, and alliances or networks may have a role in efforts to reduce perceptions of barriers to resource access (Hitt et al., 2000). Research also suggests that social capital increases entrepreneurs' illusions of control and strengthens their willingness to embrace uncertainty (DeCarolis, Litzky, \& Eddleston, 2009). Thus, market support, associated with network ties, may resolve uncertainties that have informational value to the entrepreneur and allow strategy adjustments in high EO firms (Grinstein, 2008). Covin and Slevin (1991) considered the external environment as a variety of sociocultural, as well as economic and political, forces consequently holding a moderating effect on the entrepreneur's behavior. Carlsson et al. (2013) judged all entrepreneurial activities and outcomes to 
be influenced by one or more facets of the socioeconomic environment. We examine the direct and moderating effects of a supportive environment on the network tie relationships. From the perspective of environmental impacts on firm behavior, we first hypothesize that:

H5: As the firm owners' perceptions of a supportive environment increases, so will their engagement in network ties.

\section{Moderation effects among antecedents}

Covin and Slevin's (1991) conceptual model of entrepreneurship as firm behavior included a proposed examination of external variables' moderating effects on the firm's behavior. A moderator is a type of variable that provides added information concerning the association between the predictor variable and the dependent variable. Moderating variables may temper or modulate the magnitude of the effect, thus causing the association to be strong, weaker, or possibly disappear (Allen, 2017). In our study, we consider the possible moderating effects of five variables on their association with firm engagement in network ties, herein referred to in the following hypotheses as network ties.

As stated earlier, in summarizing the literature pertaining to each variable, there are empirical findings suggesting that moderating effects may be present among the antecedents. Again, there are challenges in measuring social capital as several measures could overlap with similar concepts creating issues with multicollinearity. Another challenge could result from the possible association of different concepts with each other that are not easily distinguished but, if measured, may aid in the interpretation of their consequent effects (Engbers et al., 2017). Therefore, we examine and report the correlations among the antecedents and test for multicollinearity. Given previous findings that suggest relationships among examined antecedent variables in their effect on network ties, we hypothesize that:

H6. The relationship with network ties changes for:

a. absorptive capacity depending upon the level of social interaction, or vice versa.

b. absorptive capacity depending upon the level of business goals, or vice versa.

c. absorptive capacity depending upon the level of entrepreneurial orientation, or vice versa.

d. absorptive capacity depending upon the level of supportive environment, or vice versa. 
e. social interaction depending upon the level of business goals, or vice versa.

f. social interaction depending upon the level of entrepreneurial orientation, or vice versa.

g. social interaction depending upon the level of supportive environment, or vice versa.

h. business goals depending upon the level of entrepreneurial orientation, or vice versa.

i. business goals depending upon the level of supportive environment or vice versa.

j. entrepreneurship orientation depending upon the level of a supportive environment, or vice versa.

\section{RESEARCH METHODS AND RESULTS}

\section{Research context}

Analyses involved examination of five variables hypothesized as antecedents to engagement in network ties. First, the variables involving knowledge absorptive capacity, social interaction, business goals, entrepreneurial orientation and supportive environment were examined to determine their ability to explain, individually, their engagement in network ties. Second, the potential overlaps among the antecedents were examined for their mutual ability to explain engagement in network ties. We implemented the testing of these hypotheses with a national sample of entrepreneurial firm owners of U.S. apparel manufacturing firms given the lack of literature addressing networking within the fashion sector (Camarena-Gil et al., 2020). The U.S. apparel manufacturing sector is characterized by intense competition, necessitating firms to develop processes that support maintenance of competitive advantage. Some forms of collaboration, such as engagement in network ties, expediate the firm's success in particularly competitive sectors. Wigley and Provelengiou (2011) examined the market-facing strategic alliance in the fashion industry, whereas this exploratory study is focused on the backof-house activities involving U.S. apparel manufacturing.

Examination of networking strategy along the textile and apparel industry supply chain is not uncommon. Human and Provan (1996) examined manufacturing in the secondary wool products industry using a combination of qualitative and quantitative research methods. The interview data revealed four categories of resource exchange among member firms they labeled as friendship, information, competency, and business. Jarillo's (1988, 1993) strategic network research involved analysis of Benetton's Italian supply chain 
network, and Uzzi (1997) studied exchange of information among members of a New York City women's apparel manufacturers' supply chain. Boschma and Ter Wal (2007) examined knowledge networks among footwear firms in the south of Italy. Their findings linked higher levels of firm knowledge absorptive capacity with higher levels of innovation performance. CamarenaGil et al. (2020) conducted a qualitative study on two textile clusters in Spain for an examination of innovation in the textile industry and the impact of geographical and institutional proximity. They suggested increasing awareness among firms as to the value of sharing strategic resources and the potential transfer of knowledge. Our current inquiry may therefore hold direct implications for the global textile industry and for firms who are seeking research-generated know-how.

\section{Data collection}

The global textile and apparel industry includes processes and production of a wide array of products resulting from fiber, fabrication, and manufacture. In this present study, we narrowed the focus for our exploration to owners of apparel manufacturing firms in the U.S. with less than 250 employees. Our goal was to achieve a representative national sample of firms conducting apparel manufacturing with a focus on smaller-sized U.S. entrepreneurial firms facing growing international competition.

Data was collected in 2019 using Qualtrics ${ }^{\circ}$ online surveys and by contacting firm owners via their e-mail and requesting participation with no incentives involved other than our indication that we wanted to learn more about their business in the current environment. We generated responses from two sample populations - within a single U.S. state, and a national U.S. sample. In this approach, we were able to capture firms that were geographically close in proximity and those that were geographically dispersed. The state sample was produced from smaller-sized firms who were participants in annual regional apparel and sewn products manufacturing meetings from 2014 to 2018. The national sample was generated from a list of firms who had registered as apparel manufacturers under the U.S. NAICS code 315 (U.S. Bureau of Labor Statistics, 2020). To correspond with the state firm size, the national list contained firms with fewer than 250 employees. Following removal of nonfunctioning e-mail addresses, 2,350 national firms and 170 state firms were contacted using the Dillman, Smyth, and Christian (2009) method. Responses from the national sample totaled 77 responses for a $3.27 \%$ response rate. The state sample totaled 48 responses completed for a $28.23 \%$ response rate. The total representative sample involved 125 apparel firm responses for a total response rate of $4.96 \%$. Though several attempts were made to increase the 
sample size, a limitation for generalizing the results to a larger population is recognized; however, the exploration of relationships among the variables was considered a first step in advancing understanding of network ties as strategy among U.S. apparel producing firms.

A test for non-response bias was performed to see if early and late respondents significantly differed in their responses (Armstrong \& Overton, 1977). Independent $t$-tests were performed on the antecedents and dependent variables including, absorptive capacity, business goals, social interaction, EO, supporting environment, and network ties. No significant differences (all $p<$. 494) were identified between the surveyed early and late respondents. This study additionally relied on self-reported data from entrepreneurs as single informants representing their firm. These single key informants were considered the most knowledgeable individuals within the firm. We follow MacKenzie and Podsakoff (2012) in that, when respondents can and are willing to provide accurate responses, their responses will be less susceptible to common method bias.

There may also be some level of common method bias introduced by having the same respondent provide information for what became the independent and dependent variables in the analyses (Gatignon, Tushman, Smith, \& Anderson, 2002; Podsakoff, MacKenzie, Lee, \& Podsakoff, 2003). We, therefore, conducted Harman's one factor test as a diagnostic technique for assessing the extent to which common method variance may be a problem (Podsakoff et al., 2003). We found entry of 34 survey items representing the six scales in a principal components factor with the solution set to one factor and with oblique rotation that the single factor accounted for $23.93 \%$ of cumulative variance in the items, which is less than the $50 \%$ level suggesting a very low risk for the presence of method bias; however, no further steps were taken to remove the presence of common method variance. Given these limitations, our results offer support for the impact of multiple antecedents on engagement in network ties.

\section{Measures of variables}

Six scales were produced for the study and for each scale a mean score was created by summing the mean score for each 7-point Likert-type item included (see Table 1 for means, standard deviations, and correlations). For measurement of network ties, we adapted existing questions from the work of Henry and Vollan (2014), Teece (1992), and Yli-Renko et al. (2001). Participating firms were to indicate their level of perceived importance in response to nine statements. The scale labeled NTSCA held a Cronbach's alpha of 0.77 . Absorptive capacity was measured from existing items adapted from research by Cohen and Levinthal (1990) and Lane and Lubatkin (1998). 
Firms were asked to indicate their level of perceived importance regarding four statements. Cronbach's alpha was 0.73 and the variable was labeled ACSCA. Social interaction was measured using three existing items, with two items measuring level of importance and one item assessing degree of agreement with the statement. Items were generated from the work by Johannisson et al. (1994) and Yli-Renko et al. (2001). Cronbach's alpha for this scale was 0.73 and labeled SISCA. Business goals were adapted from work by Kuratko, Hornsby, and Naffziger (1997) and were measured using seven items assessed for level of importance. Cronbach's alpha was 0.77 and the scale was labeled BGSCA. The scale for EO was adapted from work by Le Breton-Miller and Miller (2011), Covin and Slevin (1991), and Stam and Elfring (2008) involving innovativeness, risk taking and proactiveness. Six items were used with three assessing degree of agreement, and three assessing level of importance. Cronbach's alpha was 0.77 and labeled ENTORIENSCA. The supporting environment scale was adapted from work by Miller, Besser, Gaskill, and Sapp (2003) with five items measuring level of agreement with aspects of social and economic support in the environment. Cronbach's alpha was 0.77 and the scale was labeled SUPENVSCA. Cronbach alpha levels for all scales suggest adequate reliability (Nunnally \& Bernstein, 1994).

Examination of the scales found evidence of moderate correlations between NTSCA and the scales involving ACSCA, SISCA, BGSCA, and ENTORIENSCA and a weak correlation with SUPENVSCA with the state and national sample combined. Between the independent variables there was evidence of moderate correlations between ACSCA and each of BGSCA and ENTORIENSCA. The weakest correlations in the combined sample were between BGSCA and SUPENVSCA and between ACSCA and SUPENVSCA.

Table 1. Variable means, standard deviations, and correlations for the combined sample.

\begin{tabular}{lllllllll}
\hline Scale & $\mathbf{n}$ & Mean & $\mathrm{SD}$ & $\mathbf{r}_{\text {AC }}$ & $\mathbf{r}_{\text {SI }}$ & $\mathbf{r}_{\text {BG }}$ & $\mathbf{r}_{\text {ENTORIEN }}$ & $\mathbf{r}_{\text {SUPENV }}$ \\
\hline NTSCA & 88 & 4.70 & 0.94 & 0.62 & 0.53 & 0.46 & 0.50 & 0.32 \\
& & & & $<0.001$ & $<0.001$ & $<0.001$ & $<0.001$ & 0.003 \\
\hline ACSCA & 88 & 5.43 & 0.89 & & 0.27 & 0.53 & 0.45 & 0.06 \\
& & & & & 0.012 & $<0.001$ & $<0.001$ & 0.600 \\
\hline SISCA & 88 & 4.77 & 1.31 & & & 0.27 & 0.28 & 0.35 \\
& & & & & & 0.011 & 0.008 & 0.001 \\
\hline BGSCA & 88 & 5.27 & 0.96 & & & & 0.30 & 0.11 \\
& & & & & & & 0.005 & 0.347 \\
\hline ENTORIENSCA & 87 & 5.04 & 1.04 & & & & & 0.20 \\
& & & & & & & & \\
\hline SUPENVSCA & 81 & 4.86 & 1.06 & & & & & \\
\hline
\end{tabular}


Theory guided the selection of scales and items from existing scales. The intent was not to refine the scales through reduction of items, but to retain items derived from theory. The sample sizes for the state and the nation did not allow for separate factor analyses by location, though factor analysis was conducted on the combined sample. Location was then entered in all subsequent analyses as a control variable.

Acceptable levels of reliability and consistency were found, with Cronbach alpha values between 0.73 and 0.77 (Nunnally \& Bernstein, 1994). A factor analysis was carried out to examine the construct validity of the instrument. We followed the procedure outlined in Tabachnik and Fidell (2007) and used principal component analysis specifying oblique rotation with the six desired factors. Oblique rotation was suggested when factors in the analyses are assumed to be correlated (Gorush, 1983; Sieger et al., 2016). This analysis resulted in six components with Eigenvalues of 8.00, 3.54, 2.90, $1.92,1.66$, and 1.59 . The respective variance explained was $24.24 \%, 10.73 \%$, $8.79 \%, 5.82 \%, 5.04 \%$, and $4.72 \%$. The total variance explained was $59.35 \%$, which is just under the suggested threshold of $60 \%$ (Hinkin, 1995). For the 34 items, the factorability of the data was confirmed by the Kaiser-Meyer-Olkin (KMO) measure of sampling adequacy (Kaiser, 1970) at 0.697, thus exceeding the threshold of 0.50 (Kaiser \& Rice, 1974). In addition, Bartlett's test of sphericity was significant (chi-square $=1202.6, \mathrm{df}=528, \mathrm{p}<.001$.

Unidimensionality analyses were conducted separately for the six constructs (Danneels, 2016; Gerbing \& Anderson, 1988). For components in each of the six, corresponding items loaded on one component only, with the exception of two of the seven business goals (BJSCA) and two of the nine network ties items (NTSCA), with a factor loadings of at least 0.541 (ACSCA), 0.633 (ENTORIENSCA), 0.67 (SISCA), 0.583 (SUPENVCA). Each of the four components accounted for at least $47.5 \%$ of the variance in the respective set of items (respectively 58.4\%, 47.5\%, 65.7\%, and 53.4\%).

Hinkin (1995) stressed that scales should not be developed by removing scale items based upon the factor analyses results. Further examination of the two items in the business goals scale (BGSCA) and two items in the network ties scale (NTSCA) determined that these items held strong face validity and were critical to content and construct validity (Hinkin, 1995). To check the impact on inter item correlations, if the items were removed, the revised Cronbach alpha scores were lower than with the items included. The items were retained for this early examination of this industry segment but further scale development is warranted with larger representative sample sizes of over 150 for subsequent investigations (Guadagnoli \& Velicer, 1988). 


\section{ANALYSIS AND RESULTS}

\section{Characteristics of the sample}

To examine significant differences between the participating firm owners from the state and the national sample, we examined demographic descriptive statistics. Among the state participants, there were more female participants than among the national participants ( $31.7 \%$ versus $20.3 \%$ ). The mean age of the state participants was 49 years of age compared to 56 years of age for the national sample. Respondents from the state evaluated their level of prior knowledge as 'more than average' to 'a great deal of expertise' with a mean of 4.92 compared to the national level with a mean of 2.93 indicating 'very little' to 'an average amount of expertise'. No differences were found regarding the state or national location for the level of business success, number of employees, net profit, and level of innovation and entrepreneurship practiced by the firm. Finding significant descriptive differences between the two sample groups, we incorporated a control variable in the statistical analyses regarding the firm's location, labeled as state, and examined the combined sample populations in further analyses.

There were a total of 125 valid combined state and national responses examined for characteristics observed at the owner and the firm level. When asked, $91.8 \%$ identified themselves as entrepreneurs and were predominantly business founders $(60.8 \%)$ or had purchased the business $(18.6 \%)$. The respondents were almost evenly divided, with $52 \%$ males and $48 \%$ females. The participant age range was 28 to 83 years of age with a mean age of 53 years. In terms of education, nearly half of the respondents held bachelor's degrees or higher (47.7\%), and $72 \%$ held knowledge of the production business prior to becoming involved in their current business.

The range of business age was broad, with the youngest in year one of operation and the oldest business in existence 127 years. In quartiles, the first quartile equaled 6.5 years and the third quartile 33 years in business. The majority of the firms was in the growth or mature state of the business lifecycle (92.8\%). In terms of size, we found similarity with MacGregor's (2004) work, as the majority of the firms in the present study were small in size with 10 or less employees, averaging four full-time and two part-time employees. The participating firms in our study were consistent with the Small Business Administration's (2018) figures suggesting $80 \%$ of small business employed approximately six employees. 


\section{Direct effects}

Ordinary Least Squares regression models were fit predicting NTSCA with a state indicator ( 1 indicated the manufacturer was located in the state, 0 indicated the national sample) and the scales ACSCA, SISCA, BGSCA, ENTORIENSCA, SUPENVSCA (Table 2). Model 1 included only the state location indicator as a predictor. Models 2-6 included the state indicator, and each of the scales, individually, as predictors. Model 7 included the state indicator and all five scales as predictors. Model 8 included the state indicator, all five scales, and all two-way interactions between scales as predictors. Before fitting the models, variance inflation factors (VIF) were calculated for the model with all predictor variables, excluding interactions. All variance inflation factors were less than 2, therefore, the model was fit as specified above without multicollinearity concerns (Aiken \& West, 1991).

Evidence was found that increases in each of the scales when entered individually were significantly associated with increases in NTSCA, while accounting for location using the state indicator. Support was therefore found for H1 ACSCA (Model 2, $B=0.633, p<0.001$, Adj. $R^{2}=0.377$ ), H2 SISCA (Model 3, $B=0.366, p<0.001$, Adj. $\mathrm{R}^{2}=0.271$ ), H3 BGSCA (Model $4, B=$ $0.425, p<0.001$ Adj. $R^{2}=0.216$ ), H4 ENTORIENSCA (Model $5, B=0.437, p<$ $0.001 \mathrm{Adj} . \mathrm{R}^{2}=0.279$ ), and H5 SUPENVSCA (Model $6, B=0.234, p=0.012$, Adj. $R^{2}=0.122$ ). When all five antecedents were entered (Model 7), evidence was found for ACSCA $(B=0.320, p=0.004)$, SISCA $(B=0.195, p=0.004)$ and BGSCA ( $B=0.270, p=0.007)$, but not ENTORIENSCA $(B=0.128, p=0.118)$ and SUPENVSCA $(B=0.126, p=0.070)$.

Knowledge absorptive capacity, social interaction, and business goals were found to be significantly associated with the apparel producing firms' engagement in network ties. These findings offer support for the RBV perspective involving knowledge absorptive capacity and for social capital and network theory involving social interaction and interfirm networking. Perceptions of a supportive environment and possession of entrepreneurial orientations, though not found to be significant when all five variables were examined in the analyses, were examined further for their interactions in the analysis of potential moderating effects.

\section{Moderation effects}

In terms of examining moderation, there was not strong evidence of interaction effects between the pairs of predictors on NTSCA. The amount of variance in NTSCA explained by fitting the additive model with all five predictors controlling for state location (Model $7, \mathrm{Adj} \mathrm{R}^{2}=0.565$ ) and by 
fitting the model with all five predictors and their two-way interactions controlling for state location (Model $8, A d j . R^{2}=0.579$ ) were similar $\left(R^{2}\right.$ change $=.14$ ). There was no evidence of interactions between ACSCA and SISCA ( $B=$ $0.059, p=0.564$; H6a), ACSCA and BGSCA ( $B=0.033, p=0.744 ; \mathrm{H} 6 \mathrm{~b}), \mathrm{ACSCA}$ and ENTORIENSCA ( $B=-0.120, p=0.252 ; \mathrm{H} 6 \mathrm{c})$, ACSCA and SUPENVSCA ( $B=$ $-0.067, p=0.566 ; \mathrm{H6d})$, SISCA and BGSCA ( $B=0.040, p=0.699 ; \mathrm{H6e})$, SISCA and ENTORIENSCA ( $B=-0.022, p=0.796 ; \mathrm{H} 6 \mathrm{f})$, SISCA and SUPENVSCA ( $B=$ $0.054, p=0.468 ; \mathrm{H} 6 \mathrm{~g})$, or BGSCA and ENTORIENSCA $(B=0.086, p=0.457$; H6h). There was some support for interaction effects between BGSCA and SUPENVSCA ( $B=-0.221, p=0.067 ; \mathrm{H} 6 \mathrm{i})$ and between ENTORIENSCA and SUPENVSCA ( $B=0.201, p=0.043 ; \mathrm{H} 6 \mathrm{j}$ ). Simple slopes were examined to explore these two interaction effects on NTSCA (see Figures 1 and 2).

In terms of examining the moderation effect of a supportive environment on business goals' relationship with network ties, we found at the first quartile of SUPENVSCA (Q1 $=4.2$, Low SUPENVSCA) NTSCA increased by 0.433 (SE = $0.142, p=0.003$ ) for each one unit increase in BGSCA. This evidence suggested that NTSCA increased as BGSCA increased at low values of SUPENVSCA. At the third quartile of SUPENVSCA (Q3 $=5.8$, High SUPENVSCA) NTSCA increased by 0.079 ( $\mathrm{SE}=0.141, p=0.574$ ) for each one unit increase in BGSCA. Therefore, there was no evidence of a relationship between NTSCA and BGSCA at high levels of SUPENVSCA. These findings regarding H6i suggest that when entrepreneurs perceived low levels of support from the environment, the association of business goals with network ties appeared stronger than when the support from the environment was perceived as higher. Thus, stronger perceptions of social and economic support are suggested to lessen the business goal efforts toward engagement in network ties, and inversely low perceptions of social and economic support are suggested to increase the business goal efforts to engage in network ties.

Regarding the moderation effect of a supportive environment on entrepreneurship orientation's relationship with network ties engagement, we found at the first quartile of SUPENVSCA (Q1 = 4.20; Low SUPENVSCA), NTSCA increased by 0.017 (SE $=0.111, p=0.877$ ) for each unit increase in ENTORIENSCA. This evidence suggested that NTSCA was relatively constant at all values of ENTORIENSCA at low values of SUPENVSCA. At the third quartile of SUPENVSCA (Q3 = 5.8; High SUPENVSCA), NTSCA increased by 0.338 (SE $=0.121, p=0.007)$ for each unit increase in ENTORIENSCA. This evidence suggested that NTSCA increased as ENTORIENSCA increased at high levels of SUPENVSCA. These findings regarding $\mathrm{H} 6 \mathrm{j}$ suggest that perceived support from the environment may hold an effect on the business orientation and network tie relationship, and when high levels of support from the environment were perceived the effect of business orientation on network ties was stronger 
than when the support was weaker. Further exploration into the interaction effect between ENTORIENSCA and SUPENVSCA on NTSCA2 (H6j) should be considered in future studies.

Table 2. Unstandardized coefficients (B), standard errors (p), and p-values for all regression models fit to determine the relationship between NTSCA and the scales ACSCA, SISCA, BGSCA, ENTRIENSCA, and SUPENVSCA, accounting for location

\begin{tabular}{|c|c|c|c|c|c|c|c|c|}
\hline & $\begin{array}{l}\text { Model } \\
1\end{array}$ & $\begin{array}{l}\text { Model } \\
2\end{array}$ & $\begin{array}{l}\text { Model } \\
\mathbf{3}\end{array}$ & $\begin{array}{l}\text { Model } \\
4\end{array}$ & $\begin{array}{l}\text { Model } \\
5\end{array}$ & $\begin{array}{l}\text { Model } \\
6\end{array}$ & $\begin{array}{l}\text { Model } \\
7\end{array}$ & $\begin{array}{l}\text { Model } \\
8\end{array}$ \\
\hline Variable & $\begin{array}{l}B(S E) \\
p\end{array}$ & $\begin{array}{l}B(S E) \\
p\end{array}$ & $\begin{array}{l}B(S E) \\
p\end{array}$ & $\begin{array}{l}B(S E) \\
p\end{array}$ & $\begin{array}{l}B(S E) \\
p\end{array}$ & $\begin{array}{l}B(S E) \\
p\end{array}$ & $\begin{array}{l}B(S E) \\
p\end{array}$ & $\begin{array}{l}B(S E) \\
p\end{array}$ \\
\hline Intercept & $\begin{array}{l}4.508 \\
(0.130) \\
<0.001\end{array}$ & $\begin{array}{l}1.179 \\
(0.497) \\
0.020\end{array}$ & $\begin{array}{l}2.890 \\
(0.327) \\
<0.001\end{array}$ & $\begin{array}{l}2.337 \\
(0.501) \\
<0.001\end{array}$ & $\begin{array}{l}2.357 \\
(0.418) \\
<0.001\end{array}$ & $\begin{array}{l}3.438 \\
(0.442) \\
<0.001\end{array}$ & $\begin{array}{l}-0.686 \\
(0.567) \\
0.231\end{array}$ & $\begin{array}{l}-0.191 \\
(3.798) \\
0.960\end{array}$ \\
\hline $\begin{array}{l}\text { Location } \\
\text { (State/Nat'I) }\end{array}$ & $\begin{array}{l}0.441 \\
(0.198) \\
0.029\end{array}$ & $\begin{array}{l}0.197 \\
(0.164) \\
0.234\end{array}$ & $\begin{array}{l}0.149 \\
(0.182) \\
0.416\end{array}$ & $\begin{array}{l}0.284 \\
(0.183) \\
0.124\end{array}$ & $\begin{array}{l}0.374 \\
(0.168) \\
0.029\end{array}$ & $\begin{array}{l}0.369 \\
(0.194) \\
0.060\end{array}$ & $\begin{array}{l}0.074 \\
(0.142) \\
0.607\end{array}$ & $\begin{array}{l}0.212 \\
(0.154) \\
0.175\end{array}$ \\
\hline ACSCA & & $\begin{array}{l}0.633 \\
(0.092) \\
<0.001\end{array}$ & & & & & $\begin{array}{l}0.320 \\
(0.106) \\
0.004\end{array}$ & $\begin{array}{l}0.767 \\
(1.145) \\
0.505\end{array}$ \\
\hline SiSCA3 & & & $\begin{array}{l}0.366 \\
(0.069) \\
<0.001\end{array}$ & & & & $\begin{array}{l}0.195 \\
(0.065) \\
0.004\end{array}$ & $\begin{array}{l}-0.478 \\
(0.614) \\
0.439\end{array}$ \\
\hline BGSCA & & & & $\begin{array}{l}0.425 \\
(0.095) \\
<0.001\end{array}$ & & & $\begin{array}{l}0.270 \\
(0.097) \\
0.007\end{array}$ & $\begin{array}{l}0.554 \\
(0.981) \\
0.574\end{array}$ \\
\hline ENTORIENSCA & & & & & $\begin{array}{l}0.437 \\
(0.080) \\
<0.001\end{array}$ & & $\begin{array}{l}0.128 \\
(0.081) \\
0.118\end{array}$ & $\begin{array}{l}-0.521 \\
(0.826) \\
0.531\end{array}$ \\
\hline SUPENVSCA & & & & & & $\begin{array}{l}0.234 \\
(0.091) \\
0.012\end{array}$ & $\begin{array}{l}0.126 \\
(0.069) \\
0.070\end{array}$ & $\begin{array}{l}0.388 \\
(0.693) \\
0.577\end{array}$ \\
\hline ACSCA $\times$ SICA & & & & & & & & $\begin{array}{l}0.059 \\
(0.102) \\
0.564\end{array}$ \\
\hline $\begin{array}{l}\text { ACSCA } x \\
\text { BGSCA }\end{array}$ & & & & & & & & $\begin{array}{l}0.033 \\
(0.100) \\
0.744\end{array}$ \\
\hline $\begin{array}{l}\text { ACSCA } x \\
\text { ENTORIENSCA }\end{array}$ & & & & & & & & $\begin{array}{l}-0.120 \\
(0.104) \\
0.252\end{array}$ \\
\hline $\begin{array}{l}\text { ACSCA } x \\
\text { SUPENVSCA }\end{array}$ & & & & & & & & $\begin{array}{l}-0.067 \\
(0.116) \\
0.566\end{array}$ \\
\hline
\end{tabular}




\begin{tabular}{|c|c|c|c|c|c|c|c|c|}
\hline & $\begin{array}{l}\text { Model } \\
1\end{array}$ & $\begin{array}{l}\text { Model } \\
2\end{array}$ & $\begin{array}{l}\text { Model } \\
3\end{array}$ & $\begin{array}{l}\text { Model } \\
4\end{array}$ & $\begin{array}{l}\text { Model } \\
5\end{array}$ & $\begin{array}{l}\text { Model } \\
6\end{array}$ & $\begin{array}{l}\text { Model } \\
7\end{array}$ & $\begin{array}{l}\text { Model } \\
8\end{array}$ \\
\hline SISCA $\times$ BGSCA & & & & & & & & $\begin{array}{l}0.040 \\
(0.102) \\
0.699\end{array}$ \\
\hline $\begin{array}{l}\text { SISCA } x \\
\text { ENTORIENSCA }\end{array}$ & & & & & & & & $\begin{array}{l}-0.022 \\
(0.085) \\
0.796\end{array}$ \\
\hline $\begin{array}{l}\text { SISCA } x \\
\text { SUPENVSCA }\end{array}$ & & & & & & & & $\begin{array}{l}0.054 \\
(0.074) \\
0.468\end{array}$ \\
\hline $\begin{array}{l}\text { BGSCA } x \\
\text { ENTORIENSCA }\end{array}$ & & & & & & & & $\begin{array}{l}0.086 \\
(0.114) \\
0.457\end{array}$ \\
\hline $\begin{array}{l}\text { BGSCA } x \\
\text { SUPENVSCA }\end{array}$ & & & & & & & & $\begin{array}{l}-0.221 \\
(0.119) \\
0.067\end{array}$ \\
\hline $\begin{array}{l}\text { ENTORIENSCA } \\
\text { x SUPENVSCA }\end{array}$ & & & & & & & & $\begin{array}{l}0.201 \\
(0.097) \\
0.043\end{array}$ \\
\hline $\mathrm{n}$ & 88 & 88 & 88 & 88 & 87 & 81 & 81 & 81 \\
\hline Adj. $R^{2}$ & 0.043 & 0.377 & 0.271 & 0.216 & 0.279 & 0.122 & 0.565 & 0.579 \\
\hline
\end{tabular}

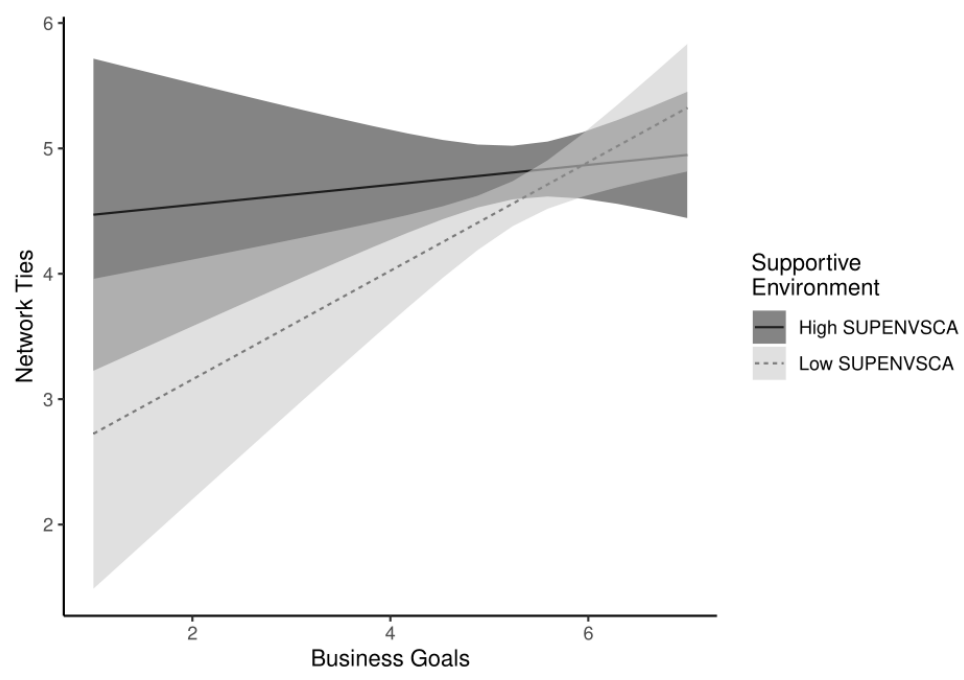

Figure 1. Interaction plot illustrating the relationship between BGSCA and NTSCA at different values of SUPENVSCA with $95 \%$ confidence bands 


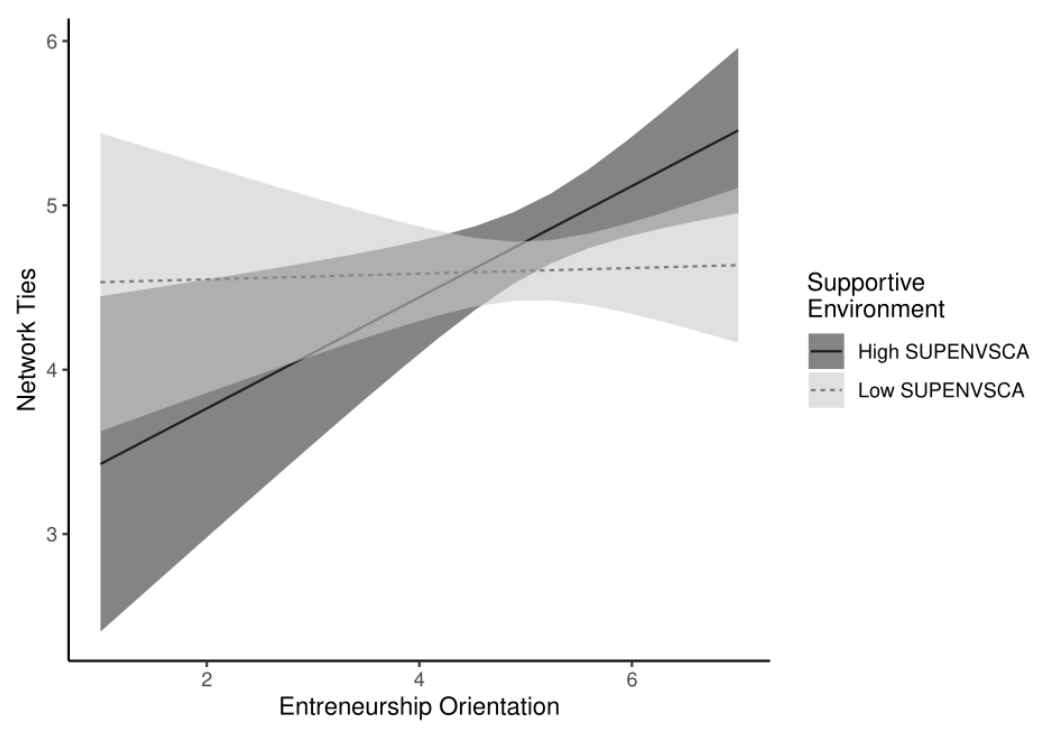

Figure 2. Interaction plot illustrating the relationship between ENTORIENSCA and NTSCA at different values of SUPENVSCA with $95 \%$ confidence bands

\section{DISCUSSION AND CONCLUSIONS}

\section{Discussion of findings}

The intent of this research was to fill some of the research voids in interorganizational networking strategy by analyzing potential antecedents and their level of association with entrepreneurial network ties. We considered engagement in network ties a strategy for addressing uncertainties and meeting competition in the business environment as previously suggested by Lavie (2006), Mazzarol et al. (2009), and Tretiakov et al. (2019). To achieve our aim, we conducted a macrolevel examination of the relationship between five management constructs and firm engagement in network ties among smallersized entrepreneurs in the U.S. apparel manufacturing industry. Theoretical constructs from the RBV perspective and from social capital's application to network theory were considered for a broader understanding of firm management efforts for leveraging networks of external ties that, with further research, may reveal new ways of exchanging and combining resources.

In our first five hypotheses, each managerial construct was examined as an antecedent for predicting the firm's level of engagement in external networking ties, while controlling for the firm's location. Findings support 
hypotheses 1 through 5 in that a firm's absorptive capacity, social interaction, business goals, EO, and perceptions of a supportive environment were each found to predict network ties significantly. We thus offer findings suggested as needed in future studies (Limaj \& Bernroider, 2017; Norman, 2004; Parra-Requena et al., 2015), particularly highlighting the importance of the firm's procurement of knowledge absorptive capacity and their engaging of network ties as a strategy for achieving knowledge resources as well as processes necessary for implementing knowledge.

With further analysis, when all five antecedents were entered in the regression analysis, we did not find evidence that EO and supportive environment continued to contribute to network ties significantly. In light of these findings, it appears that the search for knowledge and the firm's ability to incorporate the information (absorptive capacity), along with the firm's level of social interaction facilitating the exchange and gathering of ideas and resources, and the firm's established business goals are perceived to each contribute to the investment in engaging network ties as a strategy. Further research should be conducted on $\mathrm{EO}$ and supportive environment to determine in what manner they relate to network ties. There are many possibilities for why they may not be significant in the model with all five antecedents, including the potential for insufficient power due to small sample size.

Our findings confirm that each of the five management variables under consideration are associated with engagement in network ties for entrepreneurial U.S. apparel manufacturers, and that some factors moderate the strength of the relationships. It is interesting to note that EO and supportive environment held a significant moderating effect in their relationship with network ties (H6j). Perceptions of a supporting environment moderated the firm's EO, which was defined previously as risk taking, innovation, and proactiveness. Higher levels of perceived support from the environment increased the association of EO with network ties. This finding suggests that even under supporting conditions, firms perceived engaging in networking ties to address their needs for managing risk, innovation, and proactiveness. Support was also found for $\mathrm{H6i}$. Findings give evidence that the perceived supporting environment holds a moderation effect with the firm's business goals in predicting network ties, suggesting that when levels of support are low the association between business goals and engaging in network ties is higher. These findings add strength to a belief that social and economic supportive environmental conditions are important in overcoming or adapting to uncertainties (Bitowska, 2020), and firms, operating under market conditions of uncertainty, seek to engage in co-occurring network ties that cultivate social capital (Barczak, 2017). 
This research provides new insights into the benefits of directing efforts to engage in network ties as a strategy managing market challenges. From the RBV perspective, network ties are facilitated as firms seek knowledge absorptive capacity resources. Social capital theory is supported in that social interaction external to the firm serves to build network ties. Empirically determining that engagement in business network ties was greater when entrepreneurs perceived lower levels of environmental support, reinforces the long-proposed importance of social and economic influences on networking. Network theory is advanced in that business network ties were evidenced as greater when entrepreneurs held stronger entrepreneurial orientations and perceived stronger levels of environmental support. Thus, social and economic influences were found for the entrepreneurial orientation dimensions of innovativeness, risk taking, and proactiveness. These findings support conclusions from numerous prior studies and affirm that entrepreneurs perceive multiple gains to investing in relationships outside the firm. We advance the soundness of incorporating engaging in network ties as a strategy in pursuit of advantages, particularly under varying conditions of supporting environments.

\section{CONCLUSIONS}

Each of these constructs, independently and in various combinations, has been the focus of research efforts. However, understanding how the constructs specifically relate to entrepreneurial engagement in network ties as a strategic activity is important for theoretical and practical reasons. First, the contribution we believe this research makes to the literature is to link theoretically and to test empirically the relationships among five important constructs that have been conceptualized and tested independently but not examined together as multiple dimensions in relationship to network ties as a strategy for advancing the entrepreneurial firm. We shed light on how an organization's entrepreneurial decisions may contribute to engaging in networking as an entrepreneurial strategy. Second, unraveling these constructs in a theoretically driven approach is important because there were interactions among the constructs proposed to exist in practice that thus far had not been examined empirically. Our findings suggest that examination of singular antecedents may not provide a full representation of relationships with network ties. This study's approach permitted zooming in to address potential antecedents in network tie engagement as well as zooming out to see the antecedents as parts of a larger system in entrepreneurial management research. 
The substantive management constructs for entrepreneurial engagement in network ties we address here, suggest several practical applications as well as avenues for further inquiry. Next steps could include Covin and Miller's (2014) suggestion to examine network ties in assessing the EO on a national and international level as an important area in the field of strategy and organizational theory. We also see further integration of social capital and network theory with other leading perspectives in management research, for example institutional theory or resource dependence theory. There is recognition that further work is needed providing exploration into the interaction effect between entrepreneurial orientation and perceptions of a supporting environment in relation to firm engagement in network ties. We also suggest future studies are needed into the interaction among business goals and supporting environment perceptions in relation to network tie engagement. As a follow-up to this study, we recommend extended study of business goals with additions to the seven goals examined herein.

The network itself can be dynamic in that both exogenous and endogenous forces shape how networks evolve. The present study examines a defined portion of the perceived exogenous and endogenous forces shaping the entrepreneur's networking efforts. The specific networks' rules, routines and procedures requiring adherence is not part of this current study but does warrant further consideration. There are also concerns involving embeddedness, where ties or exclusivity with one firm places constraint on developing ties with other firms. Future studies could examine the firm's limits in time and resources devoted to satisfying expectations of partners in the network. Alliances made early in the firm's lifecycle may lock a firm into or out of another network. Even when a firm holds an ability to forge network ties that represent real benefits, the value of those benefits may vary as the firm or the network evolves. Future research could involve the life cycle stage of a firm in terms of implementing a network tie strategy.

Providing theoretical and practical understanding beyond the academic world provides a more comprehensive viewpoint for taking strategic actions. Our current inquiry holds direct implications for the global textile industry and for firms who are seeking research-generated know-how. Findings from this study offer impetus for building collaborations along the supply chain that align with the firm's knowledge absorptive capacity, business goals, and entrepreneurial orientation by engaging in network ties as a managerial strategy. This study offers further support that engagement in network ties is also related to social interactions and environments that support the entrepreneur. One perspective, that has offered potential solutions for smallsized apparel manufacturers in any area of the world, involves development of agile supply chains. Agility is not a new idea (Maskell, 2001) but is 
increasingly applicable in unpredictable environments and is proposed in multiple studies as an approach for strengthening supply chain relationships (Potdar, Routroy, \& Behera, 2017; Moradlou \& Asadi, 2015; Rauch, Dallasega, \& Matt, 2017). This unpredictability in environments has contributed to intensive relationship-driven operations that are information-based often employing entrepreneurial supply chain arrangements that are networkbased (Christopher, Lowson, \& Peck, 2004; Galkina \& Atkova, 2020). Given the difficulty in predicting apparel market demands, apparel companies like Zara and Benetton have employed agility strategies that involve working with specialists who are often small manufacturers (Aftab et al., 2018; Jarillo, 1993). Only those cost-efficient operations are completed in-house, while other activities, often more labor intensive, are completed by networks of small manufacturers who work collaboratively with the larger company. To achieve time and quality targets, the smaller companies are provided with technological and logistical resources. The networking strategy as applied to agile supply chain relationships warrants further examination.

This work is not without limitations. Borch and Arthur (1995) underlined one problem with the objectivist tradition of quantitative network research as studying the organization in pieces rather than overall. Therefore, a subjectivist research design using qualitative research methods or mixed methods are suggestions for future studies of concepts and relationships explored in the present study. Another risk involved in this study involves ethnocentricity in that one socio-cultural venue was examined. Due to limitations of survey research, the data collection methods may not have provided access to data that could have contributed to a broader understanding, and is not generalizable to other industries, cultures, or social economic venues. Additional study is required with participants from other countries, markets, and industries. Our measurements suffer from deficiencies and the generalizability of any findings based on a single, small sampling scheme, and these should also be considered grounds for reexamination. Further to the problem of small sample size, comes the forced restriction on the number of variables we could incorporate into the analysis. Future studies could improve the quality and reliability of findings through replication in multiple apparel manufacturing organizations within or beyond the U.S., or with entrepreneurs in other industries.

Despite deficiencies, this study represents an attempt to move from a conceptual view of interfirm social capital and network theory and a resource-based view of the entrepreneurial firm to a more concrete perspective of entrepreneurial network tie antecedents. The work offers additional confirmation that network ties offer one stratagem for enduring environmental threats. These findings are promising, and it is our hope this 
study has magnified the usefulness of incorporating a multi-disciplinary approach in combining business and social perspectives to further understanding of networking as strategic management.

\section{Acknowledgment}

This material is based upon work supported by the National Science Foundation's Science of Organizations Program under Grant Number 1660570. We also acknowledge assistance from Colorado State University's Graybill Statistical Lab directed by Dr. Julia Sharp

\section{References}

Adler, P. S., \& Kwon, S.-W. (2002). Social capital: Prospects for a new concept. Academy of Management Review, 27, 17- 40. https://doi.org/10.5465/ AMR.2002.5922314

Aftab, M.A., Yuanjian, Q., Kabir, N. \& Barual, Z. (2018). Super responsive supply chain: The case of Spanish fast fashion retailer Inditex-Zara. International Journal of Business and Management, 13(5), 212-227. https://doi.org/10.5539/ijbm.v13n5p212

Ahuja, G. (2000). The duality of collaboration: Inducements and opportunities in the formation of interfirm linkages. Strategic Management Journal, 21, 317-343. https://doi.org/10.1002/(SICI)10970266(200003)21:3<317::AID-SMJ90>3.0.CO;2-B

Aiken, L., \& West, S. (1991). Multiple Regression Testing and Interpreting Interactions. Newbury Park: Sage.

Aldrich, H., \& Zimmer, C. (1986). Entrepreneurship through social networks. In D. L. Sexton \& W. R. Smilor (Eds.), The Art and Science of Entrepreneurship (pp. 3-23). Cambridge, MA: Ballinger Publishing.

Allen, M. (2017). Variables, moderating types. The SAGE Encyclopedia of Communication Research Methods. Retrieved from https://methods. sagepub.com/reference/the-sage-encyclopedia-of-communicationresearch-methods/i15467.xm

Anderson, J., Berg, A., Hedrich, S., Ibanez, P., Janmark, J., \& Magnus, K-H. (2018). Is apparel manufacturing coming home? McKinsey Apparel, Fashion \& Luxury Group. Retrieved November 10, 2019, from https:// www.mckinsey.com/industries/retail/our-insights/is-apparelmanufacturing-coming-home

Anderson, B. S., Covin, J. G., \& Slevin, D. P (2009). Understanding the relationship between entrepreneurial orientation and strategic learning capability: An empirical investigation. Strategic Entrepreneurship Journal, 3, 218-240. http://doi.org/10.1002/sej.72

Andrews, K. R. (1980). The Concept of Corporate Strategy ( $2^{\text {nd }}$ ed. $)$. Homewood, IL: Richard D. Irwin. 
Armstrong, J. S. (1982). The value of formal planning for strategic decisions: Review of empirical research. Strategic Management Journal, 3(3), 197211. https://doi.org/10.1002/smj.4250030303

Armstrong, J., \& Overton, T. (1977). Estimating nonresponse bias in mail surveys. Journal of Marketing Research, 14(3), 396-402. https://doi. org/10.2307/3150783

Badaracco, Jr, Joseph, L. (1989), The Knowledge Link: How Firms Compete Through Strategic Alliances. Boston: Harvard Business School Press.

Barczak, B. (2017). Organizational network management system. In M. H. Bilgin, H. Danis, E. Demir, \& U. Can (Eds.), Proceedings of the 17th Eurasia and Economics Society Conference. Country Experiences in Economic Development, Management and Entrepreneurship (pp. 757-772). Cham, Switzerland: Springer International.

http://doi.org/10.1007/978-3-319-46319-3_48

Barney, J. (1991). The resource-based model of the firm: Origins, implications, and prospects. Special theory forum. Journal of Management, 17(1), 9798. https://doi.org/10.1177/014920639101700107

Barney, J., Wright, M., \& Ketchen, D. J. (2001). The resource-based view of the firm: Ten years after 1991. Journal of Management, 27, 625-641. https:// doi.org/10.1177/014920630102700601

Besser, T. L, \& Miller, N. J. (2010). High-risk and low-risk cooperative exchanges and perceived benefits in formal business networks. Entrepreneurship and Innovation, 11(2), 107-118. https://doi. org/10.5367/000000010791291767

Bitowska, A. (2020). The relationship between business process management and knowledge management - selected aspects from a study of companies in Poland. Journal of Entrepreneurship, Management and Innovation, 16(1), 169-193. https://doi.org/10.7341/20201616

Borch, O.J., \& Arthur, M.B. (1995). Strategic networks among small firms: Implications for strategy research methodology. Journal of Management Studies, 32(4), 419-437. https://doi.org/10.1111/j.1467-6486.1995. tb00783.x

Borgatti, S.P., \& Halgin, P. S. (2011). On network theory. Organization Science, 22(5), 1168-1181, http://dx.doi.org/10.1287/orsc.1100.0641

Boschma, R. A., \& Ter Wal, A.L.J. (2007). Knowledge networks and innovative performance in an industrial district: The case of a footwear district in the south of Italy. Industry and Innovation, 14(2), 177-199. https://doi. org/10.1080/13662710701253441

Bourdieu, P. (1986). The forms of capital. In J. Richardson, (Ed.), Handbook of Theory and Research for the Sociology of education (pp. 241-258). New York: Greenwood Press. https://doi.org/10.1002/9780470755679.ch15

Brinkmann, J., Grichnik, D., \& Kapsa, D. (2010). Should entrepreneurs plan or just storm the castle? A meta-analysis on contextual factors impacting the business planning-performance relationship in small firms. 
Journal of Business Venturing, 25(1). 24-40. https://doi.org/10.1016/j. jbusvent.2008.10.007

Brush, C. G., Greene, P. G., Hart, M. M., \& Haller, H. S. (2001). From initial idea to unique advantage: the entrepreneurial challenge of constructing a resource base. The Academy of Management Executive, 15(1), 64-80. https://doi.org/10.5465/AME.2001.4251394

Burt, R. G. (1992). The social structure of competition. In N. Nohria \& R.G. Eccles (Eds.), Networks and Organizations: Structure, Form, and Action (pp. 57 -91). Boston, MA: Harvard Business School Press.

Camarena-Gil, E., Garrigues, C., \& Puig, F. (2020). Innovating in the textile industry: An uncoordinated dance between firms and their territory? Journal of Entrepreneurship, Management and Innovation, 16 (3), 47-76. https://doi.org/10.7341/20201632

Canie, M. C. J., \& Romijnb, H. (2008). Actor networks in Strategic Niche Management: Insights from social network theory. Futures, 40, 613-629. https://doi.org/10.1016/j.futures.2007.12.005

Carlsson, B., Braunerhjelm, P., McKelvey, M., Olofsson, C., Persson, L., \& Ylinenpaa, H. (2013). The evolving domain of entrepreneurship research. Small Business Economics, 41, 913-930. http://doi.org/10.1007/s11187013-9503-y

Christopher, M., Lowson, R., \& Peck, H. (2004). Creating agile supply chains in the fashion industry. International Journal of Retail \& Distribution Management, 32(80), 367-376. https://doi. org $/ 10.1108 / 09590550410546188$

Cohen, W. H., \& Levinthal, D. A. (1990). Absorptive Capacity: A New Perspective on Learning and Innovation. Administrative Science Quarterly, 35(1), 128-152. https://www.jstor.org/stable/2393553

Coleman, J. S. (1988). Social capital in the creation of human capital. American Journal of Sociology, 94, 595-121

Connelly, C., \& Kelloway, K. (2003). Predictors of employees' perceptions of knowledge sharing cultures. Leadership \& Organization of Development Journal, 24(5), 294-301. https://doi.org/10.1108/01437730310485815

Covin, J. G., \& Lumpkin, G. T. (2011). Entrepreneurial Orientation theory and research: Reflections on a needed construct. Entrepreneurship, Theory and Practice, 43(1), 855-871. https://doi.org/10.1111/j.15406520.2011.00482.x

Covin, J. G., \& Miller, D. (2014). International entrepreneurial orientation: Conceptual considerations, research themes, measurement issues, and future directions. Entrepreneurship Theory and Practice, 38(1), 11-44. https://doi.org/10.1111/etap.12027

Covin, J. G., \& Slevin, D. P. (1991). A conceptual model of entrepreneurship as firm behavior. Entrepreneurship Theory and Practice, 16(1), 7-25. https://doi.org/10.1177/104225879101600102 
Covin, J. G., \& Wales, W. J. (2019). Crafting high-impact entrepreneurial orientation research:Somesuggestedguidelines. Entrepreneurship Theory and Practice, 43(10), 3-18. https://doi.org/10.1177/1042258718773181

Craig, T., McNamara, T., Descubes, I., \& Guerin, F. (2020). Manufacturing SMEs, network governance and global supply chains. Journal of Small Business and Enterprise Development, 27(1), 130-147. http://doi.org/10.1108/ JSBED-10-2019-0334

Danneels, E. (2016). Survey measures of first-and second-order competencies. Strategic Management Journal, 37, 2174-2188.

DeCarolis, D. M, Litzky, B. E., \& Eddleston, K. A, (2009). Why networks enhance the progress of new venture creation: The influence of social capital and cognition. Entrepreneurship Theory and Practice, 33(2), 527-545. https:// doi.org/10.1111/j.1540-6520.2009.00302.x

Dillman, D. A., Smyth, J. D., \& Christian, L. M. (2009). Internet, Mail, and Mixed-Mode Surveys: The Tailored Design Method (3rd Ed). Hoboken, N.J.: John Wiley \& Sons.

Dollinger, M. J. (1990). The evolution of collective strategies in fragmented industries. Academy of Management Review, 15(2), 266-285. https:// doi.org/10.5465/amr.1990.4308157

Dubini, P., \& Aldrich, H. (1991). Personal and extended networks are central to the entrepreneurial process. Journal of Business Venturing, 6, 305313. https://doi.org/10.1016/0883-9026(91)90021-5

Eisenhardt, K. M., \& Schoonhoven, C.B. (1996). Resource-based view of strategic alliance formation: Strategic and social effects in entrepreneurial firms. Organization Science, 7(2), 136-150. https://www.jstor.org/ stable/2634977

Engbers, T. A., Thompson, M. F., \& Slaper, T. F. (2017). Theory and measurement in social capital research. Social Indicators Research, 132, 537-558. http://doi.org/10.1007/s11205-016-1299-0

Felipe, C. M., Roldán, J. L., \& Leal-Rodríguez, A. L. (2017), Impact of organizational culture values on organizational agility. Sustainability, 9(12), 2-23.

Ford, D., \& Mouzas, S. (2013). The theory and practice of business networking. Industrial Marketing Management, 42(3), 433-442. http:// doi.org/10.1016/j.indmarman.2013.02.012

Fuller-Love, N., \& Thomas, E. (2004). Networks in small manufacturing firms. Journal of Small Business and Enterprise Development, 11(2), 244-253. http://doi.org/10.1108/14626000410537182

Galkina, T., \& Atkova, I. (2020). Effectual networks as complex adaptive systems: Exploring dynamic and structural factors of emergence. Entrepreneurship Theory and Practice, 44(5), 964-995. http://doi. org/10.1177/1042258719879670

Gannon, B., \& Roberts, J. (2020). Social capital: Exploring the theory and empirical data. Empirical Economics, 58, 899-919. http://doi. org/10.1007/s00181-018-1556-y 
Garvin, D. (1993). Building a learning organization. Harvard Business Review, 7 (July-August). 78-91. Retrieved October 31, 2020, from https://hbr. org/1993/07/building-a-learning-organization

Gatignon, H., Tushman, M. L., Smith, W., \& Anderson, P. (2002). A structural approach to assessing innovation construct development of innovation locus, type, and characteristics. Management Sciences, 48, 1103-1122.

Gerber Technology (2019, June 4). Made-in-the-USA Apparel Manufacturing: The Journey, the Resurgence and Solutions to Meet a Growing Demand. Gerber Technology. Retrieved January 16, 2020, from https://www. gerbertechnology.com/news/made-in-the-usa-apparel-manufacturingthe-journey-the-resurgence-and-solutions-to-meet-a-growing-demand/

Gerbing, D.W., \& Anderson, J. C. (1988). An updated paradigm for scale development incorporating unidimensionality and its assessment. Journal of Marketing Research, 25(2), 186-192. https://doi. org/10.1177/002224378802500207

Gorush, R. (1983). Factor Analysis (2 ${ }^{\text {nd }} e d$.). Hillsdale, N.J.: Laurence Erlbaum Associates.

Granovetter, M. S. (1973). The strength of weak ties. American Journal of Sociology, 78, 1360-1380. https://doi.org/10.1086/225469

Granovetter, M. S. (1985). Economic action and social structure: The problem of embeddedness. American Journal of Sociology, 91, 481-510. https:// doi.org/10.1086/228311

Granovetter, M.S. (1992). Economic institutions as social constructions: A framework for analysis. Acta Sociologica, 35(1), 3-11. https://doi. org/10.1177/000169939203500101

Greve, A., \& Salaff, J. W. (2001). The development of corporate social capital in complex innovation processes. Research in the Sociology of Organizations: Social capital of Organizations, 18, 107-134. https://doi. org/10.1016/S0733-558X(01)18005-5

Grichnik, D., Brinckmann, J., Singh, L., \& Manigart, S. (2014). Beyond environmental scarcity: Human and social capital as driving forces of bootstrapping activities. Journal of Business Venturing, 29(2), 310-326. https://doi.org/10.1016/j.jbusvent.2013.02.006

Gristein, A. (2008). The relationships between market orientation and alternative strategic orientations. European Journal of Marketing, 42(1/2), 115-134. https://doi.org/10.1108/03090560810840934

Guadagnoli, E. \& Velicer, W.F. (1988). Relation of sample size to the stability of component patterns. Psychological Bulletin, 102(2), 265-275.

Gulati, R. (1999). Network location and learning: the influence of network resources and firm capabilities on alliance formation. Strategic Management Journal, 20(5), 397-420. https://doi.org/10.1002/ (SICI)1097-0266(199905)20:5<397::AID-SMJ35>3.0.CO;2-K

Guliati, R., Lavie, D., \& Madhavan, R. (2011). How do networks matter? The performance effects of organizational networks. Research in 
Organizational Behavior, 31, 207-224. http://doi.org/10.1016/j. riob.2011.09.005

Gulati, R, Nohria, N., \& Zaheer, A. (2000). Strategic networks. Strategic Management Journal, 21(3), 203-215. https://doi.org/10.1002/ (SICl)1097-0266(200003)21:3<203::AID-SMJ102>3.0.CO;2-K

Gynawali, D., \& Fogel, D.S. (2014). Environments for entrepreneurship research development: Key dimensions and research implications. Entrepreneurship Theory and Practice, 18(4), 43-62. https://doi. org/10.1177/104225879401800403

Hakansson, H., \& Snehota, I. (1989). No business is an island: The network concept of business strategy. Scandinavian Journal of Management, 5(3), 187-200. https://doi.org/10.1016/0956-5221(89)90026-2

Henry, A. D., \& Vollan, B. (2014). Networks and the challenge of sustainable development,

Annual Review of Environment and Resources, 39, 583-610. https://doi. org/10.1146/annurev-environ-101813-013246.

Hinkin, T. R. (1995). A review of scale development practices in the study of organizations. Journal of Management, 21(5), 967-988.

Hitt, M. A., Dacin, T., Levitas, E., Arregle, J-L., \& Borza, A. (2000). Partner selection in emerging and developed market contexts: Resource-based and organizational learning perspectives. The Academy of Management Journal, 43(3), 449-467. https://doi.org/10.2307/155640

Hoang, H., \& Antoncic, B. (2003). Network-based research in entrepreneurship: A critical review. Journal of Business Venturing, 18(2), 165-187. http:// doi.org/10.1016/S0883-9026(02)00081-2.

Human, S. E., \& Provan, K. G. (1996). External resource exchange and perceptions of competitiveness within organizational networks: An organizational learning perspective. In P. D. Reynolds, S. Birley, J. E. Butler, W. Bygrave, P. Davidson, W. B. Gartner, \& P. P. McDougall (Eds.), Frontiers of Entrepreneurship Research: Proceedings of the $16^{\text {th }}$ Annual Entrepreneurship Research Conference (pp. 241-252). Boston, MA: Babson College.

Ibarra, H. (1992). Structural alignments, individual strategies, and managerial action: Elements toward a network theory of getting things done. In $\mathrm{N}$. Nohria \& R.G. Eccles (Eds.), Networks and Organizations: Structure, Form, and Action (pp. 165-188). Boston, MA: Harvard Business School Press.

Ibarra, H. (1993). Network centrality, power, and innovation involvement: Determinants of technical and administrative roles. Academy of Management Journal, 36(3), 471-501. https://doi.org/10.5465/256589

Jarillo, J. C. (1988). On Strategic Networks. Strategic Management Journal, 9 (1), 31-41. https://doi.org/10.1002/smj.4250090104.

Jarillo, J. C. (1993). Strategic Networks: Creating the Borderless Organization. Oxford, UK: Butterworth Heinemann. https://doi.org/10.1016/C2013-006541-3 
Johannisson, B. (1986). Network strategies: Management technology for entrepreneurship and change. International Small Business Journal, 5(1), 19-30. https://doi.org/10.1177/026624268600500102

Johannisson, B. (1996). The dynamics of entrepreneurial networks. In P. D. Reynolds, S. Birley, J. E. Butler, W. Bygrave, P. Davidson, W. B. Gartner, \& P. P. McDougall (Eds.), Frontiers of Entrepreneurship Research: Proceedings of the $16^{\text {th }}$ Annual Entrepreneurship Research Conference (pp. 253-267). Boston, MA: Babson College.

Johannisson, B., Alexanderson, O., Nowici, K., \& Senneseth, K. (1994). Beyond anarchy and organizations: Entrepreneurs in contextual networks. Entrepreneurship \& Regional Development, 6(4), 329-356. https://doi. org/10.1080/08985629400000020.

Jones, C., Hesterly, W. S., \& Borgatti, S. P. (1997) A general theory of network governance: Exchange, conditions and social mechanisms. Academy of Management Review, 22(4), 911-945. https://doi.org/10.5465/ amr.1997.9711022109

Kaiser, H. F. (1970). A second generation little jiffy. Psychometrika, 35, 401-445.

Kaiser, H. F. \& Rice, J. (1974). Little jiffy, mark IV. Educational and Psychological Measurement, 34, 111-117.

Kelliher, F., Murphy, M., \& Harrington, D (2020). Exploring the role of goal setting and external accountability mechanisms in embedding strategic learning plans in small firms. Journal of Small Business Enterprise Development, 27(5), 705-725. http://doi.org/10.1108/JSBED-12-2019-0411

Kim, T.-Y., Oh, H., \& Swaminathan, A. (2006). Framing interorganizational network change: A network inertia perspective. Academy of Management Review, 31, 704-720. https://doi.org/10.5465/amr.2006.21318926

Kotey, B., \& Meredith, G.G. (1997). Relationships among owner/manager personal values, business strategies, and enterprise performance. Journal of Small Business Management, 35(2), 37-63.

Kreiser, P. M. (2011). Entrepreneurial orientation and organizational learning: The impact of network range and network closure. Entrepreneurship Theory and Practice, 35(5), 1025-1050. https://doi.org/10.1111/j.15406520.2011.00449.x

Kuratko, D. F., Hornsby, J. S., \& Naffziger, D. W. (1997). An examination of owner's goals in sustaining entrepreneurship. Journal of Small Business Management, 35(1), 24-33.

Krzakiewicz, K., \& Cyfert, S. (2013). The network concept pf strategic management and its limitations. Management, 17(2), 19-30. http://doi. org/10.2478/manment-2013-0002

Lane, P. J., \& Lubatkin, M. (1998). Relative absorptive capacity and interorganizational learning. Strategic Management Journal, 18, 461477. https://doi.org/10.1002/(SICI)1097-0266(199805)19:5<461::AIDSMJ953>3.0.CO;2-L 
Larson, A., \& Starr, J. A. (1993). A network model of organization formation. Entrepreneurship Theory and Practice, 17(2), 5-15. https://doi. org $/ 10.1177 / 104225879301700201$

Latham, G. P., \& Locke, E. A. (1991). Self-regulation through goal setting. Organizational Behavior and Human Decision Processes, 50(2), 212-247. https://doi.org/10.1016/0749-5978(91)90021-K

La Breton-Miller, I., \& Miller, D. (2011). Governance, social identity, and entrepreneurial orientation in closely held public companies. Entrepreneurship Theory and Practice, 35(5), 1051-1076. https://doi. org/10.1111/j.1540-6520.2011.00447.x

Lavie, D. (2006). The competitive advantage of interconnected firms: An extension of the resource-based view. Academy of Management Review, 31(3), 638-658. http://dx.doi.org/10.5465/AMR.2006.21318922

Lee, D. Y., \& Tsang, E. W. K. (2001). The effects of entrepreneurial personality, background and network activities on venture growth. Journal of Management Studies, 38(4), 583-602. https://doi.org/10.1111/14676486.00250

Leyden, D.P., Link, A.N., \& Siegel, D.S. (2014). A theoretical analysis of the role of social networks in entrepreneurship. Research Policy, 43, 1157-1163. http://dx.doi.org/10.1016/j.respol.2014.04.010

Li, Y., Cui, V., \& Liu, H. (2017). Dyadic specific investments, absorptive capacity, and manufacturers' market knowledge acquisition: Evidence from manufacturer-distributor dyads. Journal of Business Research, 78, 323-331. https://doi.org/10.1016/j.jbusres.2016.12.028

Limaj, E. \& Bernroider, E.W. (2017). The roles of absorptive capacity and cultural balance for exploratory and exploitative innovation in SMEs. Journal of Business Research, 94,137-153. https://doi.org/10.1016/j. jbusres.2017.10.052

Linder, C., Lechner, C., \& Pelzel, F. (2020). Many roads lead to Rome: How human, social, and financial capital are related to new venture survival. Entrepreneurship Theory and Practice, 44(5), 909-932. https://doi. org/10.1177/1042258719867558

Lis, A., \& Sudolska, A. (2017). Inter-and intra-firm learning synergy through integrating absorptive capacity and employee suggestion processes: The case study of Frauenthal Automotive Torun company. Journal of Entrepreneurship, Management and Innovation, 13(1), 25-68. https:// doi.org/10.7341/20171312

Liu, H.-M., \& Yang, H.-F. (2020). Network resource meets organizational agility: Creating an idiosyncratic competitive advantage for SMEs. Management Decision, 58(1), 58-75. https://doi.org?10.1108/MD-10-2017-1061

Locke, D. A, Latham, G. P., \& Erez, M. (1988). Determinants of goal commitment. Academy of Management Review, 13(1), 23-39.

MacGregor, R. C. (2004). Factors associated with formal networking regional small business: Some findings from a study of Swedish SMEs. Journal 
of Small Business and Enterprise Development, 11(1), 60-74. htt ps://10.1108/14626000410519100.

MacKenzie, S. B., \& Podsakoff, P. M. (2012). Common method bias in marketing causes, mechanisms and procedural remedies. Journal of Retailing, 88(4), 542-585. https://doi.org/10.1016/j.jretai.2012.08.001

Marcela Herrera Bernal, S., Burr, C., \& Johnsen, R. E. (2002). Competitor networks: International competitiveness through collaboration: The case of small freight forwarders in the High-Tech Forwarder Network. International Journal of Entrepreneurial Behavior \& Research, 8(5), 239-253. https://doi.org/10.1108/13552550210448348

McGowan, P, Cooper, S., Durkin, M., \& O'Kane, C. (2015). The influence of social and human capital in developing young women as entrepreneurial business leaders. Journal of Small Business Management, 53(3), 645661. https://doi.org/10.1111/jsbm.12176

Maskell, B. (2001). The age of agile manufacturing. Supply Chain Management: An International Journal, 6(1), 5-11. https://doi. org $/ 10.1108 / 13598540110380868$

Mazzarol, T., Roboud, S., \& Soutar, G. N. (2009). Strategic planning in growth oriented small firms. International Journal of Entrepreneurial Behavior \& Research, 15(4), 320-345. https://doi.org/10.1108/13522751011053626

Miller, N. J., Besser, T., Gaskill, L. A., \& Sapp, S. G. (2003). Community and managerial predictors of performance in small rural U.S. retail and service firms, Journal of Retailing and Consumer Services, 10(4), 215230. https://doi.org/10.1016/S0969-6989(02)00012-7

Miller, N. J., Besser, T., Malshe, A. (2007). Strategic networking among small businesses in small US communities. International Small Business Journal, 25(6), 631-5665. https://doi.org/10.1177/0266242607082525.

Miller, N. J., Besser, T. L., \& Sattler Weber, S. (2010). Networking as marketing strategy: A case study of small community businesses. Qualitative Market Research: An International Journal, 13(3), 253-270. https://doi. org/10.1108/13522751011053626

Mittelhauser, M. (1997). Employment trends in textiles and apparel: 19732005. Monthly Labor Review. Bureau of Labor Statistics, 24-35.

Molina-morales, F. X., \& Martinez-fernandez, M. T. (2010). Social networks: Effects of social capital on firm innovation. Journal of Small Business Management, 48(2), 258-279. https://doi.org/10.1111/j.1540627X.2010.00294.x

Moliterno, T. P., \& Mahony, D. M. (2011). Network theory of organization: A multilevel approach. Journal of Management, 37(2), 443-467. http:// doi.org/10.1177/0149206310371692

Moradlou, H., \& Asadi, M. (2015). Implementation of agile manufacturing principles in small and medium enterprises (SMES). Journal of Modern Processes in Manufacturing and Production, 4(3), 31-44. 
Nahapiet, J., \& Ghoshal, S. (1998). Social capital, intellectual capital, and the organizational advantage. Academy of Management Review, 23(2), 242266. https://doi.org/10.5465/amr.1998.533225

Nicholson, C., Compeau, L. D., \& Sethi, R. (2001). The role of interpersonal liking in building trust in long-term channel relationships. Journal of the Academy of Marketing Science, 29(1), 3-15. https://doi. org/10.1177/0092070301291001

Norman, P. M. (2004). Knowledge acquisition, knowledge loss, and satisfaction in high technology alliances. Journal of Business Research, 57, 610-619. https://doi.org/10.1016/S0148-2963(02)00395-8

Nunnally, J. C., \& Bernstein, I. H. (1994). Psychometric Theory (3 ${ }^{\text {rd }}$ ed.). New York: McGraw Hill.

Nyuur, R. B., Brecic, R., \& Debrah, Y.A. (2018). SME international innovation and strategic adaptiveness: The role of domestic network density, centrality and informality. International Marketing Review, 35(2), 280300. https://doi.org/10.1108/IMR-11-2015-0239.

Paliokaite, A. (2019). An innovation policy framework for upgrading firm absorptive capacities in the context of catching-up economies. Journal of Entrepreneurship, Management and Innovation, 15(3), 103-130. https:// doi.org/10.7341/20191534

Parra-Requena, G., Ruiz-Ortega, M. J., Garcia-Villaverde, P. M., \& RodrigoAlarcon, J., (2015). The mediating role of knowledge acquisition on the relationship between external social capital and innovativeness. European Management Review, 12(3), 149-169.

Payne, G.T., Moore, C.B., Griffis, S. E., \& Autry, C. W. (2011). Multilevel challenges and opportunities in social capital research. Journal of Management, 37(2), 491-520. https://doi.org/10.1177/0149206310372413

Pellinen, K. (2014). The interplay of entrepreneurial and network activities in the entrepreneurial process: A relational analysis. International Journal of Entrepreneurship and Innovation, 15(1), 17-28. https://doi. org/10.5367/ijei.2014.0137

Podsakoff, P. M., MacKenzie, S. B., Lee, J-L, \& Podsakoff, N. P. (2003). Common method biases in behavior research: A critical review of the literature and recommended remedies. Journal of Applied Psychology, 88(5), 879903. https://10.1037/0021-9010.88.5.879

Portes, A. (1998). Social capital: Its origins and applications in modern sociology. Annual Review of Sociology, 24(1), 1-24. https://doi. org/10.1146/annurev.soc.24.1.1

Potdar, P. K., Routon, S., \& Behera, A. (2017). Analyzing the agile manufacturing barriers using fuzzy DEMATEL. Benchmarking: An International Journal, 24(7), 1912-1936. http://doi.org/10.1108/BIJ-02-2016-0024.

Putnam, R. D. (1995). Tuning in, tuning out: The strange disappearance of social capital in America. PS: Political Science and Politics, 28(4), 664-683. https://doi.org/10.2307/420517 
Putnam, R. D. (2000). Bowling Alone: The Collapse and Revival of American Community. New York: Simon \& Shuster. https://doi. org $/ 10.1145 / 358916.361990$

Rauch, E., Dallasega, P., \& Matt, D. T. (2017). Distributed manufacturing network models of smart and agile minifactories. International Journal of Agile Systems and Management, 10(3/4), 185-205.

Rehman, N.U. (2015). Network alliances and firms' performances a panel data analysis of Pakistani SMEs. Eurasian Economic Review, November. http://doi.org/10.1007/s40821-015-0033-1

Rezaei, J., \& Ortt, R. (2018). Entrepreneurial orientation and firm performance: The mediating role of functional performances. Management Research Review, 11(7), 878-900. https://doi.org/10.1108/MRR413-2017-0092

Sieger, P., Gruber, M., Fauchart, E., \& Zellweger, T. (2016). Measuring the social identity of entrepreneurs: Scale development and internal validation. Journal of Busines Venturing, 31, 542-572. https://doi.org/10.1016/j. jbusvent.2016.07.001

Siren, C., Hakala, H., Wincent, J., \& Grichnik, D. (2017). Breaking the routines: Entrepreneurial orientation, strategic learning, firm size, and age. Long Range Planning, 50(2), 145-167. https://doi.org/10.1016/j. Irp.2016.09.005

Small Business Administration, Office of Advocacy. (2018). Frequently Asked Questions About Small Businesses. Retrieved May 2, 2020, from www. sba.gov/sites/default/files/ advocacy/Frequently-Asked-QuestionsSmall-Business-2018.pdf

Smeltzer, L. R., Van Hook, B. L., \& Hutt, R. W. (1991). Analysis and use of advisors as information sources in venture startups. Journal of Small Business Management, 29(3), 10-20.

Sobolewska, O. (2020). Knowledge-oriented business process management as a catalyst to the existence of network organization. Journal of Entrepreneurship Management and Innovation, 16(1), 107-132. https:// doi.org/10.7341/20201614

Stam, W., \& Elfring, T. (2008). Entrepreneurial orientation and new venture performance: The moderating role of intra- and in extraindustry social capital. The Academy of Management Journal, 51(1), 97-111. https:// doi.org/10.5465/amj.2008.30744031

Tabachnik, B. G., \& Fidell, L. S. (2007). Using Multivariant Statistics (5 ${ }^{\text {th }}$ ed.). New York: Allyn and Bacon/Pearson education.

Teece, D. (1992). Competition, cooperation, and innovation: Organizational arrangements for regimes of technological progress. Journal of Economic Behavior and Organization, 18(1), 1-25. https://doi.org/10.1016/01672681(92)90050-L

Tenkasi, R.V., \& Chesmore, M.C. (2003). Social networks and planned organizational change. The Journal of Applied Behavioral Science, 39(3), 281-300. https://doi.org/10.1177/0021886303258338 
The Apparel Industry. (2017). Offshoring of production and global job shifts. Duke University. Retrieved March 29, 2020, from https://sites.duke.edu/ sociol342d_01d_s2017_team-7/5-offshoring-of-production-and-globaljob-shifts-unfinished/

Thoma, J., \& Zimmermann, V. (2020). Interactive learning - The key to innovation in non-R\&D-intensive SMES? A cluster analysis approach. Journal of Small Business Management, 58(4), 747-776. https://doi.org/ 10.1080/00472778.2019.1671702

Thorelli, H. B. (1986). Networks: Between markets and hierarchies. Strategic Management Journal, 7(1), 37-51. https://doi.org/10.1002/ smj.4250070105

Timmons, J. (1999). New Venture Creation: Entrepreneurship for the Twentyfirst Century ( $5^{\text {th }}$ ed.). Boston: McGraw-Hill International.

Todeva, E. (2014, July 14). Business network theory and the role of country of origin [Abstract]. XVIII ISA World Congress of Sociology Facing an Unequal World: Challenges for Global Sociology. Retrieved March 15, 2021, from https://isaconf.confex.com/isaconf/wc2014/webprogram/ Paper67029.html

Toutain, O., Fayoll, A., Pittaway, L., \& Politis, D. (2017). Role and impact of the environment on entrepreneurial learning. Entrepreneurship \& Regional Development, 29(9-10), 869-888. https://doi.org/10.1080/08985626.20 17.1376517

Tretiakov, A., Bensemann, A., Sanders, J., \& Golloway, L. (2019). The perceived importance of external ties and the performance of small owner-managed firms. The International Journal of Entrepreneurship and Innovation, 20(3), 209-219. https://doi.org/10.1177/1465750318808940

Tsai, W., \& Ghoshal, S. (1998). Social capital and value creation: The role of intrafirm networks. The Academy of Management Journal, 41(4). 464476. https://doi.org/10.5465/257085

U.S. Bureau of Labor Statistics. (2020). Apparel manufacturing: NAICS 315. Retrieved October 30, 2020, from https://www.bls.gov/iag/tgs/iag315.htm

Uzzi, B. (1996). The sources and consequences of embeddedness for the economic performance of organizations: The network effect. American Sociological Review, 61, 674-698. https://doi.org/10.2307/2096399

Uzzi, B. (1997). Social structure and competition in interfirm networks: The paradox of embeddedness. Administrative Sciences Quarterly, 42, 35-47. https://doi.org/10.2307/2393808

van Gelderen, M., van de Sluis, L., \& Jansen, P. (2005). Learning opportunities and learning behaviors of small business starters: Relations with goal achievement, skill development and satisfaction. Small Business Economics, 25(1), 97-108. https://doi.org/10.1007/s11187-005-4260-1

Wigley, S. W., \& Provelengiou, A-K. (2011). Market-facing strategic alliances in the fashion sector. Journal of Fashion Marketing and Management, 15(2), 141-162. http://doi.org/10.1108/13612021111132609 
Williams Jr., R. I., Manley, S. C., Aaron, J. R., \& Daniel, F. (2018). The relationship between a strategic comprehensive strategic approach and small business performance. Journal of Small Business Strategy, 28(2), 33-48. ISSN: 1081-8510 (Print) 2380-1751 (Online)

Woolcock, M. (1998). Social capital and economic development: Toward a theoretical synthesis and policy framework. Theory and Society, 27, 151-208. https://doi.org/10.1023/A:1006884930135

Yli-Renko, H., Autio, E., \& Sapienza, H. J. (2001). Social capital, knowledge acquisition, and knowledge exploitation in young technology-based firms. Strategic Management Journal, 22(6/7), 587-613. https://www. jstor.org/stable/3094322

Zbierowski, P. (2020). The mystery of high performance-mediation by entrepreneurial orientation and organizational citizenship behavior. Journal of Entrepreneurship, Management and Innovation, 16(2), 67-91. https://doi.org/10.7341/20201623

Zin, M.L.M., \& Ibrahim. H. (2020). The influence of entrepreneurial supports on business performance among rural entrepreneurs. Annals of Contemporary Developments in Management and $H R, 2(1), 31-41$. https://doi.org/10.33166//ACDMHR.2020.01.004

\begin{abstract}
Abstrakt
CEL: Firmy nie rozwijajq się i nie prosperujq wyłącznie dzięki własnym indywidualnym wysiłkom, ponieważ każda firma jest pod wpływem działań innych, a zatem bezpośrednie i pośrednie relacje kształtujq strategiczne zarzqdzanie firmq. Relacje te tworzq taktykę, dzięki której wiedza i inne strategicznie ważne zasoby sq dostępne i tworzone. Nawiqzywanie i podtrzymywanie więzi między członkami sieci było przedmiotem licznych badań w literaturze społecznej, ekonomicznej i biznesowej. Nasza praca opiera się na zasobowym spojrzeniu na perspektywę firmy wraz z teoriq kapitału społecznego i jej wspólnymi konstrukcjami w teorii sieci. Wcześniejsze ustalenia sugerujq, że powiqzania sieciowe sq strategicznymi działaniami generowanymi na rzecz rozwoju i kontynuacji firmy. Więzi mogq być krótkotrwałe lub przerodzić się $w$ relacje długoterminowe. Celem tego badania jest wypełnienie niektórych luk w strategii sieci międzyorganizacyjnych poprzez analizę pięciu poprzedników , przedstawionych $w$ literaturze jako podmioty indywidualnie zwiqzane z zaangażowaniem przedsiębiorców w powiq̨zania sieciowe. W ten sposób nasza praca zapewnia kolejnq ścieżkę badawczq do badania wkładu sieci w zarzqdzanie strategiczne. Postawiliśmy hipotezę o pozytywnych powiqzaniach z zaangażowaniem przedsiębiorców w powiqzania sieciowe z poprzednikami obejmujacymi zdolność do przyswajania wiedzy firmy, cele biznesowe, orientację na przedsiębiorczość, interakcje społeczne i wsparcie ze strony otoczenia. METODYKA: W naszym podejściu ilościowym przetestowaliśmy proponowane przez nas bezpośrednie i moderujqce powiqzania na poziomie makro za pomocq ankiety internetowej przeprowadzonej wśród 125 amerykańskich firm produkujqcych odzież. Sektor produkcji odzieży w Stanach Zjednoczonych, podobnie jak w wielu krajach, boryka się z wieloma zakłócajq̨cymi czynnikami, które przyczyniaja się do
\end{abstract}


spadku kontynuacji działalności tego sektora. WYNIKI: Wyniki analiz regresji OLS potwierdzaja nasze hipotetyczne powiqzania, ponieważ każdy z pięciu poprzedników znaczqco przyczynit się do zaangażowania przedsiębiorców w powiqzania sieciowe; jednak, gdy wszystkie pięć zostało zbadanych łącznie, istotne były tylko chłonność, interakcje społeczne i cele biznesowe $\left(R^{2}=0,58\right)$. Dalsze badanie efektów moderacji wykazało, że postrzeganie przez przedsiębiorców środowiska wspierajq̨cego modyfikuje zarówno orientację przedsiębiorczq, jak i cele biznesowe. IMPLIKACJE DLA TEORII I PRAKTYKI: Wpływ otoczenia na relacje celów biznesowych z więzami sieciowymi był większy, gdy postrzeganie otoczenia jako wspierajqcego zmniejszyło się, podczas gdy wpływ otoczenia na relacje orientacji przedsiębiorczej z więzami sieciowymi był większy, gdy postrzegano otoczenie jako wspierajqce, co sugeruje dalsze badanie postrzegania otoczenia przez amerykańskich przedsiębiorców.Przedsiębiorcy zainteresowani budowaniem krajowych i międzynarodowych powiqzań w ramach łańcucha dostaw mogq uznać, że powiqzania sieciowe sq jednym z rozwiqzań umożliwiajqcych dostosowanie zasobów firmy do globalnej konkurencyjności. Przyszłe badania moga skierować uwagę na inne sektory przemysłu lub kraje w celu replikacji z większymi rozmiarami próbek, ponieważ zdajemy sobie sprawę z ograniczeń w uogólnianiu i udoskonalaniu skali ze względu na naszq ograniczonq wielkość próby. ORYGINALNOŚĆ I WARTOŚĆ: Zbadanie pięciu konstruktów, które rzucajq światło na to, jak decyzje organizacji mogq odnosić się do angażowania się w sieci, oraz przedstawienie teoretycznych i praktycznych implikacji, które przyczyniajq się do większego zrozumienia systemu organizacyjnego.

Słowa kluczowe: chłonność, interakcja społeczna, cele biznesowe, orientacja przedsiębiorcza, środowisko wspierajqce, powiqzania sieciowe

\section{Biographical notes}

Nancy J. Miller, Ph.D., is a professor in the Department of Design and Merchandising. She has conducted thirty years of collaborative research involving family businesses, exchange in rural marketplaces, and with a variety of business networks both existing and emerging. In addition to qualitative and quantitative investigations into the context of rural and small communities, her work has focused on the socio-economic aspects of micro to medium-sized apparel retailers and U.S. manufacturing firms.

Carol Engel-Enright, Ph.D., has forty years of experience in small apparel design and manufacturing businesses. Her work and research include small business entrepreneurship and freelance design working with small businesses. She founded the Denver Design Incubator, which works with new enterprises in product development and small industrial manufacturing. She has worked with co-design projects for international artisans and fairtrade organizations in contemporary product development and manufacturing. 
David A. Brown is a Ph.D. candidate in Statistics at Colorado State University and a graduate student collaborator in the Graybill Statistics and Data Science Laboratory at Colorado State University. His research focuses on survey statistics, specifically nonresponse adjustments and evaluating adaptive designs for mixed-mode surveys.

\section{Conflicts of interest}

The authors declare no conflict of interest.

\section{Citation}

Miller, N. J., Engel-Enright, C., \& Brown, D. A. (2021). Direct and moderation effects on U.S. apparel manufacturers' engagement in network ties. Journal of Entrepreneurship, Management and Innovation, 17(3), 67-113. https:// doi.org/10.7341/20211733 
